\title{
Effect of Initial pH and Organic Matter Concentration on Production of Volatile Organic Acids Through Acidogenesis of Sugarcane Vinasse
}

Juliana Martins ${ }^{1}$, Hugo Valença de Araújo ${ }^{2}$, Gustavo Mockaitis ${ }^{1}$, Ariovaldo José da Silva ${ }^{1 *}$.

${ }^{1}$ School of Agricultural Engineering (FEAGRI), University of Campinas (UNICAMP), Av. Cândido Rondon, 501, Barão Geraldo, Campinas, São Paulo 13083-875, Brazil.

${ }^{2}$ Technology Center (CTEC), Federal University of Alagoas (UFAL), Campus A. C. Simões, Av. Lourival Melo Mota, Tabuleiro dos Martins, Maceió, Alagoas 57072-970, Brazil.

${ }^{*}$ Corresponding author: Ariovaldo José da Silva. ORCID 0000-0002-9171-8776, arijs@unicamp.br

\section{ABSTRACT}

Sugarcane vinasse is an industrial liquid waste generated in great amounts in Brazilian ethanol industries. Nowadays its main use occurs at sugarcane crops, where vinasse is applied as a nutrient source for fertirrigation. However, continued use of vinasse in soil can cause several environmental impacts. So, aiming to provide a more environmentally friendly destination to the effluent, the goal of this work was to investigate the acidogenesis using a synthetic vinasse as substrate, focusing on the effects of initial $\mathrm{pH}$ and Chemical Oxygen Demand (COD) on short chain organic acids (SCOAs) concentrations. Synthetic vinasse was prepared at laboratory taking some real sugarcane vinasse composition given in previous works as references. So, major contribution presented here is the investigation on obtaining high added-value SCOAs from a simulated effluent. Cattle manure sludge was utilized as inoculum to promote the conversion of carbohydrate (sucrose, Suc) in synthetic vinasse into SCOAs in batch reactors during a total incubation time of $72 \mathrm{~h}$. Acidogenesis profiles have shown that concentration of lactic acid (HLa) was prevailing among all metabolites, indicating that process followed through an essentially lactic route. Furthermore, considerable concentrations of propionic, acetic and isobutyric acids were also verified at some specific operation times, while solventogenesis was not detected at all. The greatest peak of lactate content was $4.96 \mathrm{~g} \mathrm{HLa} \mathrm{L}^{-1}$, observed under initial $\mathrm{pH} 6.0$ and $25 \mathrm{~g} \mathrm{COD} \mathrm{L}^{-1}$, at $16 \mathrm{~h}$. Maximum of lactate productivity was $332.10 \mathrm{~g} \mathrm{HLa} \mathrm{L}^{-1} \mathrm{~h}^{-1}$ at $8 \mathrm{~h}$, associated to a yield of $189.14 \mathrm{~g}$ HLa (g Suc) ${ }^{-1}$, under initial $\mathrm{pH} 7.5$ and $20 \mathrm{~g} \mathrm{COD} \mathrm{L}^{-1}$.

Keywords: anaerobic digestion, lactic acid, batch reactors, cattle manure sludge. 


\section{INTRODUCTION}

Generation of agroindustrial wastes in great amounts has drawn attention to the final disposition given to them, which should be realized in such a way to minimize impacts on receiving bodies since effluents generally present high pollution potential. In sugar and ethanol production process from sugarcane, both products of high economic importance in countries such as Brazil, two main residues are obtained, namely sugarcane bagasse and vinasse. Thus, renewability of ethanol fuel depends strongly on the destination these waste materials receive. Since a long time sugarcane bagasse has been successfully utilized in generation of steam and electricity by means of its burning in boilers existing in sugar and alcohol industrial units (DIAS et al., 2015). Vinasse, although traditionally applied as a nutrient source for fertirrigation in sugarcane crops, can cause severe environmental problems mainly if its use is continued, so that unconventional processing of it have been the target of several works more or less recently (HOARAU et al., 2018)

It is expected that ethanol production will grow in the coming years and reaches 134 billion of liters in 2024, with United States, Brazil, European Union and China as the world's largest producers (OECD, 2015). In 2018, United States was responsible for $56 \%$ of all ethanol generated in planet. Also in 2018 , production was equivalent to about half of the American in Brazil (28\%) (RFA, 2019), highlighting the importance of Brazilian ethanol in the global context. So, vinasse is indeed a relevant agroindustrial waste in Brazil, generated as a liquid by-product in hydrous ethanol purification system. It is an acidic ( $\mathrm{pH} 3.5-5.0$ ), dark brown coloured and unpleasant odour stream with a high organic load, implying a high Chemical Oxygen Demand (COD) (HOARAU et al., 2018).

Some previous studies has already pointed out that use of vinasse as a fertilizer may have positive consequences for sugarcane crops (BRITO et al., 2009; JIANG et al., 2012; UYEDA et al., 2013; PREVINA \& SARAVANAM, 2013; FUESS e GARCIA, 2014), which is its main use nowadays. However, Fuess and Garcia (2014) highlighted some important disadvantages, mostly observed if vinasse is continuously disposed on soil, namely salinization and sodification, organic overloading, permanent acidification of water bodies, interference in the photosynthesis of aquatic plants and inhibition of seed 
germination. These negative effects has motivated strongly the search for alternative processes aiming the degradation of sugarcane vinasse.

Sugar and ethanol factories generate an average of $156 \mathrm{~L}$ of vinasse and $250 \mathrm{~kg}$ of bagasse for each ton of sugarcane processed, providing $12 \mathrm{~L}$ of ethanol and $94 \mathrm{~kg}$ of sugar (sucrose). Therefore, an average ratio of $13 \mathrm{~L}$ of vinasse by liter of ethanol is attained (GUNKEL et al., 2006), which can varies widely as a function of production process parameters (feedstock quality, ethanol fermentation yield, and so on). Based on these data, perspective is that 1,742 billion of liters of vinasse are to be generated until 2024 (HOARAU et al., 2018). Such a great volume of agroindustrial waste is very significant and various methods to convert it into value-added products, especially chemical compounds and energy carriers, have been investigated (FUESS et al., 2020; MORAES et al., 2019).

In the context of SCOAs biological production using vinasses resulting from ethanol generation from sugarcane, sugar-beet and other agricultural feedstocks (or synthetic vinasses in order to simulate the real ones), lactic acid (also named lactate) is certainly the most focused metabolite because of its great versatility, since it can be used as an acidifying and flavouring agent, leather softener, antimicrobial preservative and chemical input. A highlighting application of lactic acid occurs as a precursor for the synthesis of polylactic acid polymers in pharmaceutical and plastic industries due to its favourable attributes of biodegradability, biocompatibility and elasticity (HOARAU et al., 2018).

Many microorganisms species and processes have been applied to produce lactic acid from vinasse as substrate. Liu et al. (2012) used a method based on combined application of microwave and $\mathrm{NaOH}$ pre-treatments in order to reduce contents of hemicellulose and lignin in vinasse, resulting in a higher lactate yield in comparison to the case in which each pre-treatment was executed separately. Lactic fermentation of vinasse by zeolite-immobilized cells of Lactobacillus rhamnosus ATCC 7469 was performed by Djukić-Vuković et al. (2013), which concluded that support material used was effective to promote the process. Similarly, Djukić-Vuković et al. (2016) employed the same 
microbial strain, but using a Mg-modified zeolite to cell retention, also obtaining considerable high yields and productivities in batch experiments.

Djukić-Vuković et al. (2015) analysed lactate production from vinasse by batch fermentation with Lactobacillus rhamnosus ATCC 7469, reaching higher reaction performance parameters in comparison to other residual substrates, even though vinasse has not been supplemented with nitrogen and other materials. Additionally, as process by-product, Djukić-Vuković et al. (2015) obtained a dry solid suitable for feeding of monogastric animals. Employing microorganisms of a mixed culture from an Upflow Anaerobic Sludge Blanket (UASB) reactor and immobilized over particles of a Greek volcanic rock and yalumina, Lappa et al. (2015a) and Lappa et al. (2015b) detected lactate as the prevailing metabolite in continuous acidogenesis tests with vinasse as feed stream.

Moraes et al. (2019) claimed the existence of a lack in technical literature concerning works exploring the production of SCOAs and alcohols by vinasse anaerobic digestion. In addition to lactic acid, acetic and butyric acids (acetate and butyrate) have also been synthesized via acidogenesis using vinasse as substrate (LAPPA et al., 2015a; MORAES et al., 2019; FUESS et al., 2020). Butyric acid finds applications as precursor for biological fermentative production of butanol by Clostridium spp. and also as raw material for food, beverages, chemical, textile and pharmaceutical industries (ZHANG et al., 2009). However, number of works dealing with SCOAs and alcohols production by vinasse anaerobic digestion is indeed scarce to the present date probably due to the strong emphasis that has been given almost exclusively to hydrogen and methane $\left(\mathrm{H}_{2}\right.$ and $\left.\mathrm{CH}_{4}\right)$ generation, which can be executed by means of more mature and practical biotechnological processes (BAGHCHEHSARAEE et al., 2008; MORAES et al., 2015; FUESS e ZAIAT, 2018).

In this work, the main goal was to carry out acidogenesis batch experiments to evaluate effects of initial $\mathrm{pH}$ and $\mathrm{COD}$ of a synthetic vinasse on the production of SCOAs. A synthetic vinasse prepared in laboratory was used because it allows a better control of substrate parameters aiming to verify more easily the operating conditions leading to maximization of desirable metabolites contents. By doing this, great variability of real vinasse characteristics, which is 
typical for the industrial waste, was avoided. Thus, major contribution presented here is the investigation on obtaining high added-value SCOAs from a simulated effluent that has been processed mostly focusing on the production of biogas for use as biofuel.

\section{MATERIAL AND METHODS}

\subsection{Experimental design}

Volatile acids production experiments were performed in $500 \mathrm{~mL}$ Duran ${ }^{\odot}$ flasks, in which $300 \mathrm{~mL}$ was working volume, while $200 \mathrm{~mL}$ was taken as headspace. Reactor bulk was constituted by $270 \mathrm{~mL}$ of the corresponding media and $30 \mathrm{~mL}$ of inoculum at $24.33 \mathrm{~g}$ TVS (Total Volatile Solids) $\mathrm{L}^{-1}$. Therefore, initial inoculum concentration was kept constant in all experiments at $2.4 \mathrm{~g} \mathrm{TVS} \mathrm{L}^{-1}$.

Flasks were maintained in an orbital shaker-incubator to be subjected to a constant rotational speed of $100 \mathrm{~min}^{-1}$, under controlled temperature $\left(37^{\circ} \mathrm{C}\right)$. Initial $\mathrm{pH}$ of each medium was adjusted by adding sodium bicarbonate $\left(\mathrm{NaHCO}_{3}\right)$. To ensure an anaerobic condition to all experiments, nitrogen was fluxed at constant flow rate in all flasks for $10 \mathrm{~min}$. All experiments were conducted for $72 \mathrm{~h}$ and samples of media were collected for monitoring of reactors every $8 \mathrm{~h}$. Table 1 shows the experimental design used in this study.

Table 1 - Matrix of experiments for evaluating the effects of initial $\mathrm{pH}$ and $\mathrm{COD}$ on SCOAs and alcohols production.

\begin{tabular}{ccc}
\hline Reactors & $\begin{array}{c}\mathbf{C O D} \\
\left(\mathbf{g ~ O}_{\mathbf{2}} \mathbf{L}^{-1}\right)\end{array}$ & $\mathbf{p H}$ \\
\hline B1 & 20 & 4.5 \\
B2 & 30 & 4.5 \\
B3 & 20 & 7.5 \\
B4 & 30 & 7.5 \\
B5 & 25 & 6.0 \\
B6 & 25 & 6.0 \\
B7 & 25 & 6.0 \\
\hline
\end{tabular}




\section{$2.2 \quad$ Media}

Media was prepared considering the organic matter composition as defined by Godoi et al. (2017) and the characterization of the vinasse from sugarcane as determined by Moraes et al. (2019). A complex synthetic media was used in this study rather than real vinasse due to the variation of composition and concentration in real vinasse could undermine the conclusions. However, the media used in this work shows similarity with real vinasse. Table 1 shows the concentration and composition of each media used in this experiment.

Table 1 - Compositions of synthetic media for different $C O D_{\text {sol. }}$

\begin{tabular}{|c|c|c|c|}
\hline \multirow{2}{*}{$\begin{array}{l}\text { Component } \\
\mathrm{COD}_{\mathrm{sol}}\left(\mathrm{g} \mathrm{O}_{2} \mathrm{~L}^{-1}\right)\end{array}$} & \multicolumn{3}{|c|}{ Concentration } \\
\hline & 20 & 25 & 30 \\
\hline Sucrose $\left(g_{\text {Suc L }}{ }^{-1}\right)$ & 12 & 15 & 18 \\
\hline Propionic acid (g HPr L $\left.{ }^{-1}\right)$ & 0.50 & 0.63 & 0.75 \\
\hline Butyric acid $\left(\mathrm{g} \mathrm{HBu} \mathrm{L}^{-1}\right)$ & 0.70 & 0.88 & 1.05 \\
\hline Acetic acid $\left(\mathrm{g} \mathrm{HAc} \mathrm{L}^{-1}\right)$ & 1.30 & 1.63 & 1.95 \\
\hline Ethanol $\left(\mathrm{g} \mathrm{EtOH} \mathrm{L}^{-1}\right)$ & 1.50 & 1.88 & 2.25 \\
\hline Nitrogen $\left(\mathrm{g} \mathrm{N} \mathrm{L}^{-1}\right)$ & 0.80 & 1.00 & 1.20 \\
\hline Sulphur (g S-SO $\left.{ }_{4}^{2-} \mathrm{L}^{-1}\right)$ & 1.00 & 1.25 & 1.50 \\
\hline Potassium $\left(\mathrm{g} \mathrm{K} \mathrm{L}^{-1}\right)$ & 2.20 & 2.75 & 3.30 \\
\hline Calcium (g Ca L ${ }^{-1}$ ) & 0.44 & 0.55 & 0.66 \\
\hline Magnesium (g Mn L ${ }^{-1}$ ) & 0.25 & 0.31 & 0.38 \\
\hline Sodium ( $\mathrm{g} \mathrm{Na} \mathrm{L}^{-1}$ ) & 0.52 & 0.65 & 0.78 \\
\hline Phosphorus (mg P-PO ${ }_{4}^{3-} \mathrm{L}^{-1}$ ) & 70.0 & 87.5 & 105 \\
\hline Phenol (mg L $\left.{ }^{-1}\right)$ & 6.0 & 7.5 & 9.0 \\
\hline $\operatorname{Iron}\left(\mathrm{mg} \mathrm{Fe} \mathrm{L}^{-1}\right)$ & 10.0 & 12.5 & 15.0 \\
\hline Manganese $\left(\mathrm{mg} \mathrm{Mn} \mathrm{L}^{-1}\right)$ & 3.00 & 3.75 & 4.50 \\
\hline Zinc (mg Zn L L $\left.{ }^{-1}\right)$ & 0.40 & 0.50 & 0.60 \\
\hline Copper (mg Cu L $\left.\mathrm{L}^{-1}\right)$ & 0.30 & 0.38 & 0.45 \\
\hline Nickel (mg Ni L-1) & 0.20 & 0.25 & 0.30 \\
\hline Lead (mg Pb L'-1) & 0.20 & 0.25 & 0.30 \\
\hline Cadmium (mg Cd L ${ }^{-1}$ ) & 0.08 & 0.10 & 0.12 \\
\hline
\end{tabular}

\subsection{Inoculum}

Inoculum used in batch experiments of this work came from an anaerobic reactor treating cattle manure. After collecting, the anaerobic sludge was 
subjected to an thermal-acidic pre-treatment, based on the procedures and results found by Mockaitis et al. (2020). This pre-treatment was performed only select only microorganisms which are capable of performing hydrolysis and acidogenesis, inhibiting methanogenesis.

Sludge thermal-acidic pre-treatment was performed prior inoculation. The water from the sludge was drained using a $1.0 \mathrm{~mm}$ mesh sieve and then heated in a water bath at $80^{\circ} \mathrm{C}$ for $30 \mathrm{~min}$. Afterwards, sludge was cooled down to environmental temperature $\left(25-30^{\circ} \mathrm{C}\right)$ using an ice bath. After cooling, $\mathrm{pH}$ value was set to 3.0 by the addition of hydrochloric acid $(\mathrm{HCl}) 1.0 \mathrm{~mol} \mathrm{~L}^{-1}$. Subsequently, the inoculum was stored in a refrigeration chamber at $4{ }^{\circ} \mathrm{C}$ for 24 h. Finally, sludge $\mathrm{pH}$ was increased to 6.98 by the addition of sodium hydroxide $(\mathrm{NaOH}) 1.0 \mathrm{~mol} \mathrm{~L}^{-1}$.

\subsection{Analytical methods}

The following parameters were analysed for all samples collected from batch reactors (respective analytical methods are in parentheses): $\mathrm{pH}(4,500-$ $\mathrm{H}+$ electrometric method) (APHA, 2012), total sugar content (carbohydrate to sucrose - colorimetric method at wavelength $\lambda=490 \mathrm{~nm}$ ) (DUBOIS et al., 1956) and cellular growth (optical density, OD, directly linked to medium turbidity, considering a wavelength $\lambda=600 \mathrm{~nm}$ ). OD analyses were conducted by reading absorbances of samples diluted with distilled water in the proportion 1:5 (BEGOT et al., 1996).

SCOAs and alcohols in samples were evaluated by means of High Performance Liquid Chromatography (HPLC, Shimadzu Scientific Instruments $\left.^{\odot}\right)$. HPLC was equipped with a degasifier (DGU-20A ${ }^{3 R}$ ), two parallel

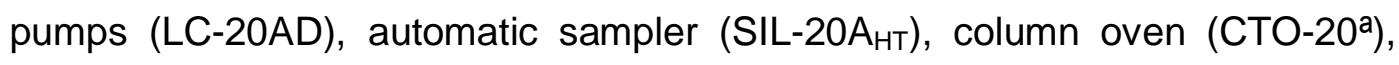
ultraviolet detector (UV-DAD) executing the reading at $\lambda=210 \mathrm{~nm}\left(\mathrm{SDP}-20^{\mathrm{a}}\right)$,

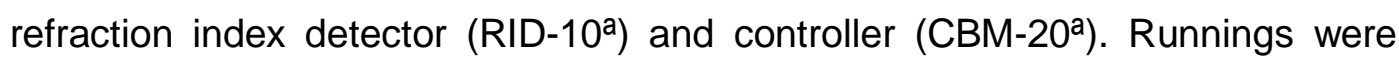
carried out in an Aminex column HPX-87H (300 mm x $7.8 \mathrm{~mm}$, BioRad ${ }^{\circledR}$ ) keeping a fixed oven temperature of $43^{\circ} \mathrm{C}$. Mobile phase was an aqueous solution of sulfuric acid $\left(\mathrm{H}_{2} \mathrm{SO}_{4}\right) 0.005 \mathrm{~mol} \mathrm{~L}^{-1}$ at a flow rate of $0.5 \mathrm{~mL} \mathrm{~min}^{-1}$. Injected volume of each sample (pre-filtered and under $\mathrm{pH} \sim 2.0$ ) in HPLC was 
$100 \mu \mathrm{L}$. Identification of peaks and initial analyses of chromatograms were realized by means of LC Solution Shimadzu ${ }^{\odot}$ software.

\subsection{Performance analysis}

Performance of batch experiments was evaluated based on parameters such as productivity $\left(P, \mathrm{mg} \operatorname{SCOA~L}{ }^{-1} \mathrm{~h}^{-1}\right)$ and yield $\left(Y, \mathrm{mg} \operatorname{SCOA}(\mathrm{g} \mathrm{Suc})^{-1}\right)$, calculated according to definitions of Eqs. (1) and (2), respectively, where $C_{m e t, t}$ is the metabolite concentration at incubation time $t\left(\mathrm{~g} \mathrm{~L}^{-1}\right) ; C_{m e t, t=0}$ is the initial concentration of metabolite (at time $t=0$ ); $C_{i}$ is the initial concentration of carboydrate ( $\mathrm{g} \mathrm{Suc}^{-1}$ ); and $t$ is the incubation time (h).

$$
\begin{aligned}
& P=\frac{C_{m e t, t}-C_{m e t, t=0}}{t} \\
& Y=\frac{C_{m e t, t}-C_{m e t, t=0}}{C_{i}}
\end{aligned}
$$

Mass balances in terms of theoretical COD were computed in order to check the consistency of experimental and theoretical results at the end of all batch tests, after $72 \mathrm{~h}$ of incubation time. Atomic mass balance equations were developed for each chemical element considering the oxidation reaction by oxygen $\left(\mathrm{O}_{2}\right)$ of $1.0 \mathrm{~mol}$ of an organic compound with general molecular formula $\mathrm{C}_{x} \mathrm{H}_{y} \mathrm{O}_{z}$ representing SCOAs, alcohols and microbial biomass.

The theoretical COD associated to each metabolite $\left(C O D_{t, m e t}\right)$ corresponds to the theoretical quantity of $\mathrm{O}_{2}$ required to oxidize completely 1.0 mol of an organic molecule $\left(\mathrm{C}_{x} \mathrm{H}_{y} \mathrm{O}_{z}\right)$. Therefore, in order to convert organic compound concentration measured experimentally by HPLC into $C O D_{t, m e t}$, it was used the ratio of $m_{\mathrm{O}_{2}}$ by $m_{\mathrm{C}_{\mathrm{x}} \mathrm{H}_{\mathrm{y}} \mathrm{O}_{\mathrm{z}}}$, which are oxygen and organic compound stoichiometric masses, in accordance to Eq. (3). Note that $x, y$ and $z$ are the numbers of carbon, hydrogen and oxygen atoms existing in organic molecule.

$$
C O D_{t, m e t}=\frac{m_{\mathrm{O}_{2}}}{m_{\mathrm{C}_{\mathrm{x}} \mathrm{H}_{\mathrm{y}} \mathrm{O}_{\mathrm{z}}}}=\frac{32 x+8 y-16 z}{12 x+y+16 z} \frac{\mathrm{mg} \mathrm{O}_{2}}{\mathrm{mg} \mathrm{C}_{\mathrm{x}} \mathrm{H}_{\mathrm{y}} \mathrm{O}_{\mathrm{z}}}
$$

Relations derived from stoichiometric for complete oxidation reactions of organic compounds were employed to compute mass balances referring to detected metabolites [Eq. (3)], sucrose (Suc) and microbial biomass (Bio). Total theoretical COD $\left(C_{C O D_{t, T}}\right)$ was determined by means of Eq. (4) as a weigthed 
sum of theoretical CODs $\left(C O D_{t, S u c}\right.$ for sucrose, $\operatorname{COD}_{t, B i o}$ for biomass and $C O D_{t, m e t}$ for each metabolite) by correspondent concentrations of all process participants $\left(C_{S u c}, C_{B i o}\right.$ and $\left.C_{m e t}, 10^{-3} \mathrm{~g} \mathrm{~L}^{-1}\right)$.

$$
\operatorname{COD}_{t, T}=C_{S u C} \operatorname{COD}_{t, S u c}+C_{B i o} \operatorname{COD}_{t, B i o}+\sum C_{m e t} \operatorname{COD}_{t, m e t}
$$

Aiming to verify the compatibility between experimental $\operatorname{COD}\left(C O D_{\text {exp }}\right)$ and total theoretical $\operatorname{COD}\left(C_{C O D_{t, T}}\right)$, a parameter called agreement $(\mathrm{Ag}, \%)$ was calculated as defined by Eq. (5). According to it, the higher the value of $\mathrm{Ag}$, the higher the compatibility between both experimental and theoretical CODs.

$$
A g=\frac{C_{C O D_{t, T}}}{C O D_{\text {exp }}} \cdot 100 \%
$$

\section{RESULTS AND DISCUSSION}

\subsection{Acidogenesis profiles}

\subsubsection{Total carbohydrate concentration, $\mathrm{pH}$, optical density (OD), total SCOAs and lactic acid (lactate) concentrations}

Figure 1 shows the time profiles of total carbohydrates concentration (a), $\mathrm{pH}$ (b) and $\mathrm{OD}$ (c) in different reactional media (B1-B7) through $72 \mathrm{~h}$ of processing time. 

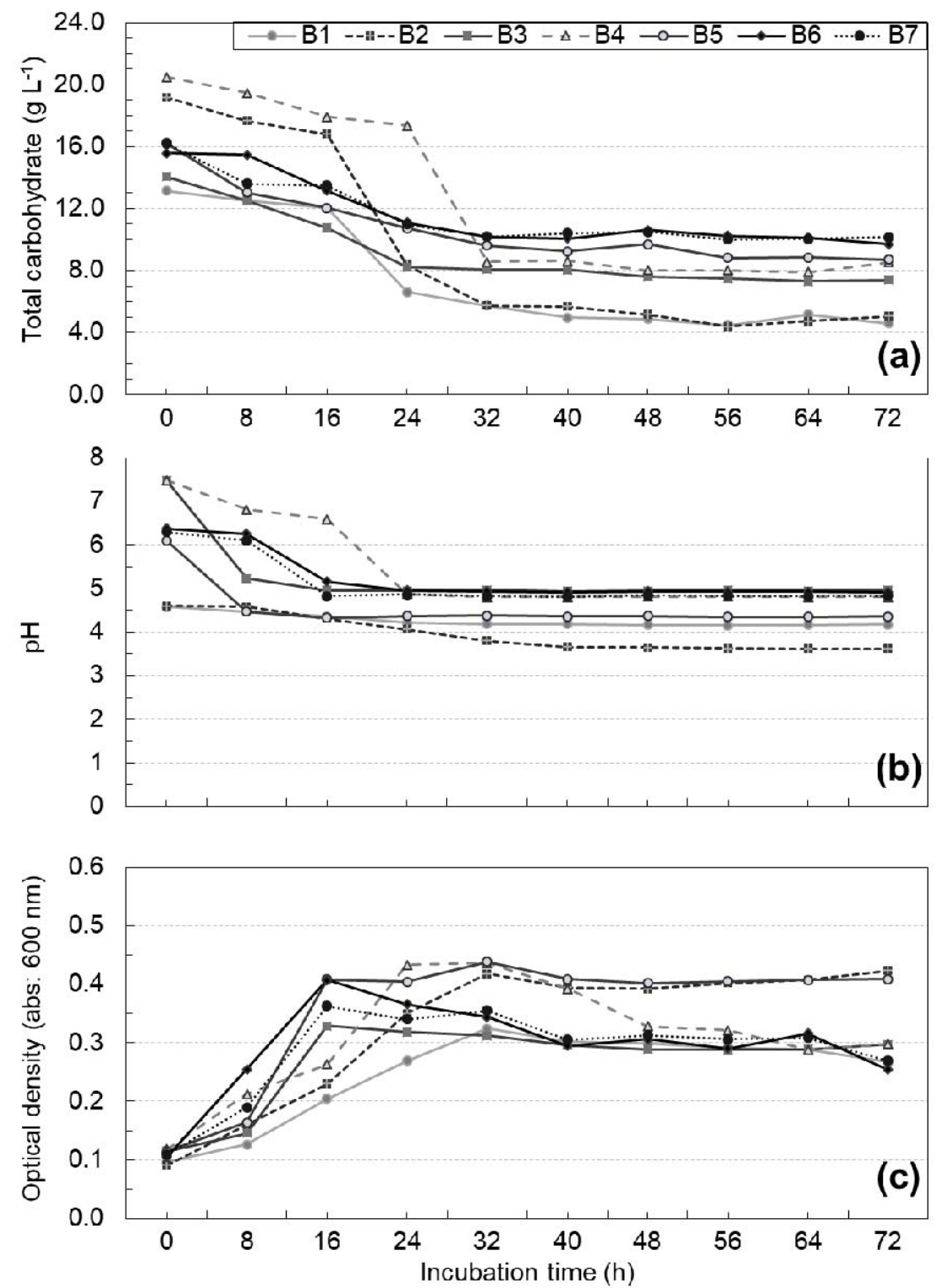

Fig. 1 - Profiles of monitoring variables in batch reactors during $72 \mathrm{~h}$ of total operation: (a) total carbohydrate concentration, (b) $\mathrm{pH}$ and (c) optical density (OD).

Carbohydrate consumption occurred mostly before $32 \mathrm{~h}$ in all studied conditions, coinciding with the increase in OD profile. This behavior shows that the carbohydrate consumption was associated with cell growth. After 24 hours, the $\mathrm{pH}$ reached a stable value for all assays.

Figure 2 shows concentration profiles of total SCOAs and lactic acid (HLac). Note that maximum of concentrations for both total SCOAs and lactic acid are coincident in Figs. $2 a$ and $2 b$, which is certainly due to lactic acid be the major metabolite. Particularly in Fig. $2 b$, it is observed that lactate 
concentration presented increasing profiles between $0 \mathrm{~h}$ and $16 \mathrm{~h}$ in reactor $\mathrm{B} 5$, $\mathrm{B} 6$ and $\mathrm{B} 7$, attaining maximum of $4.92,4.66$ and $4.96 \mathrm{~g} \mathrm{HLa} \mathrm{L}^{-1}$ at $\mathrm{pH} 4.3,5.2$ and 4.8, respectively. Probably because of reactors B5, B6 and B7 had been prepared with synthetic vinasse at the same initial $\mathrm{pH}$ and $\mathrm{COD}$, trends concerning lactate contents were similar in these media, suggesting a good experimental repeatability of results.
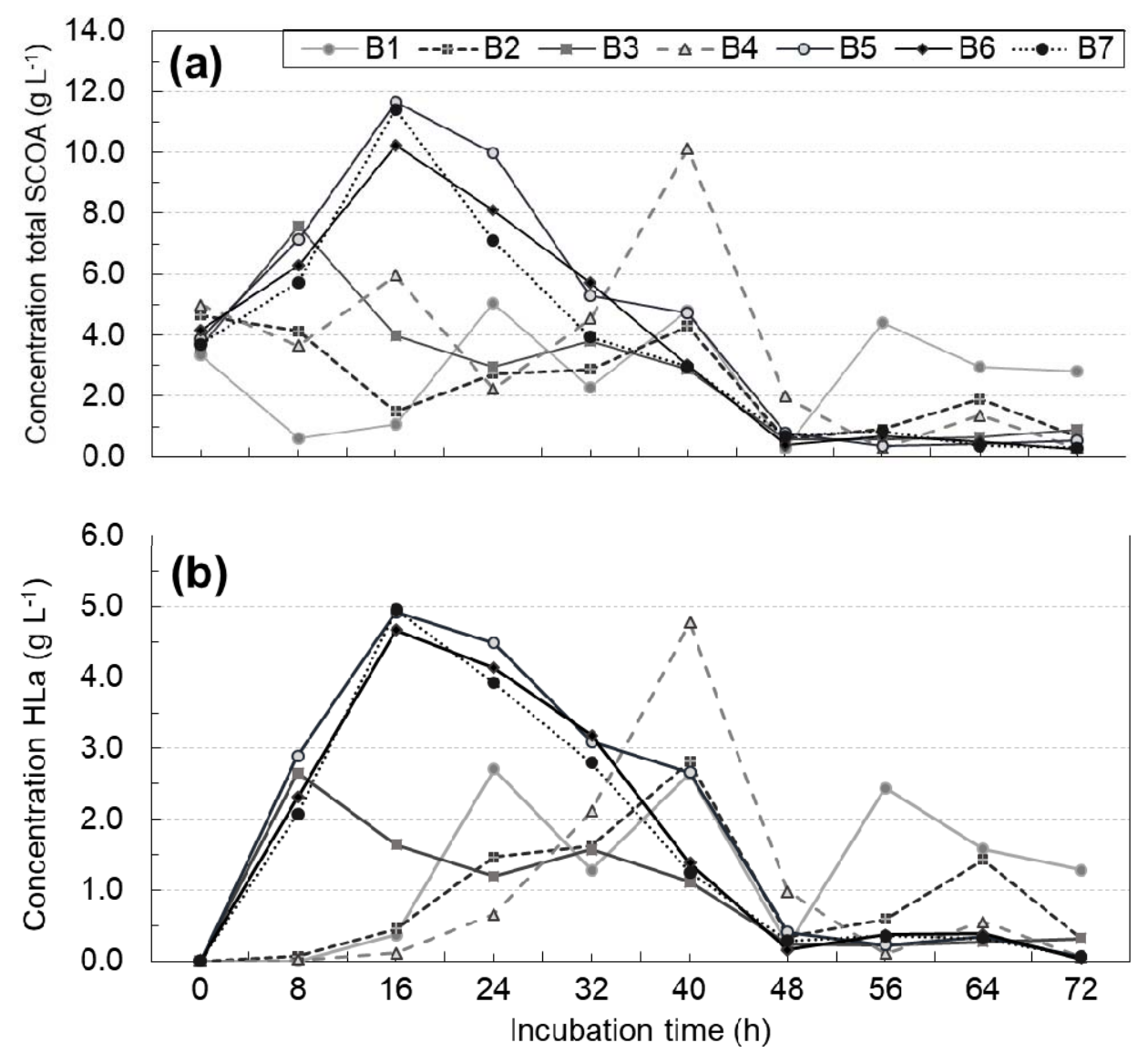

Fig. 1 - Concentration profiles in batch reactors along $72 \mathrm{~h}$ of total operation: (a) total SCOAs and (b) lactic acid (HLa).

As can also be seen in Fig. 2b, reactors B2 and B4, where initial COD of substrate was the highest one $\left(30 \mathrm{~g} \mathrm{COD} \mathrm{L}^{-1}\right)$, also showed initial increasing profiles of lactic acid concentration, although during a longer incubation period, from $0 \mathrm{~h}$ to $40 \mathrm{~h}$, attaining maximum of 2.82 and $4.77 \mathrm{~g} \mathrm{HLa} \mathrm{L}^{-1}$ at $\mathrm{pH} 3.7$ and 4.8 , respectively. This indicates a less pronounced generation trend of SCOAs at lower $\mathrm{pH}$ values, generally below 4.5 , which is in accordance with some previous results from technical literature (HAUS et al., 2011; LI et al., 2014). 
Concentration profiles of lactic (HLa), propionic (HPr), isobutyric ( $\mathrm{HIBu})$ and butyric $(\mathrm{HBu})$ acids, which were metabolites produced at the most appreciable amounts in batch reactors, are presented in Fig. 3. However, among all SCOAs generated, lactate was the one detected at higher concentrations along all batch tests, while isobutyrate showed the lowest concentrations in majority of incubation times. Besides these compounds, malic (HMa), succinic (HSu), formic (HFo), isovaleric (HIVa) and valeric (HVa) acids were also quantified, although at very small concentrations, and have also contributed to the summation resulting in total SCOAs.

In reactors $\mathrm{B} 1$ and $\mathrm{B} 3$, where initial concentrations of synthetic vinasse were the lowest ones ( $\left.20 \mathrm{~g} \mathrm{COD} \mathrm{L}^{-1}\right)$, maximum of lactic acid contents were very near each other, 2.71 and $2.66 \mathrm{~g} \mathrm{HLa} \mathrm{L}^{-1}$, occurring at $24 \mathrm{~h}$ and $8 \mathrm{~h}$, respectively, see Fig. $2 \mathrm{~b}$. In view of this, higher initial $\mathrm{pH}$ in reactor $\mathrm{B} 3$ seems to have anticipated lactate peak. In accordance to these results, number of SCOAs-producing microorganisms was probably greater at $8 \mathrm{~h}$ in reactor B3, which presented an OD 0.145 against an OD 0.126 in reactor B1 at the same incubation time, as shown if Fig. 1c. Additionally, in a general manner, except for reactor B1, all other batch reactors exhibited decreasing lactate concentration profiles right after reaching peaks of concentration at specific incubation times, showing an almost constant behaviour from $48 \mathrm{~h}$ to $72 \mathrm{~h}$.

Using food waste from a restaurant as substrate $\left(\mathrm{COD}_{\text {sol }} \sim 53 \mathrm{~g} \mathrm{O}_{2} \mathrm{~L}^{-1}\right)$, Zhang et al. (2005) realized batch tests in order to evaluate influence of $\mathrm{pH}$ in hydrolysis and acidogenesis without addition of any extra inoculum (only the ones already existing in food waste were applied to degrade it). In three of four $\mathrm{pH}$ levels examined (namely 5, 9 and 11), lactate was obtained at considerable concentrations, often predominant compared to those of formiate, acetate, propionate and butyrate. Similar trends were observed by Wang et al. (2001) and Wang (2002), which also assessed anaerobic processing of food wastes using mixed cultures, although both works have focused solely on lactic acid production.

Under $\mathrm{pH} \mathrm{5,} \mathrm{acidic} \mathrm{value} \mathrm{that} \mathrm{could} \mathrm{disfavour} \mathrm{the} \mathrm{production} \mathrm{of} \mathrm{SCOAs}$ by Clostridium strains (HAUS et al., 2011), concentrations of lactic acid (HLa), formic acid (HFo), acetic acid (HAc), propionic acid (HPr) and butyric acid ( $\mathrm{HBu})$ 
attained by Zhang et al. (2005) were $14.9 \mathrm{~g} \mathrm{HLa} \mathrm{L}^{-1}, 1.7 \mathrm{~g} \mathrm{HFo} \mathrm{L}^{-1}, 1.0 \mathrm{~g} \mathrm{HAc} \mathrm{L}^{-}$ 1 ,

$\mathrm{g} \mathrm{HPr} \mathrm{L}^{-1}$ and $18.5 \mathrm{~g} \mathrm{HBu} \mathrm{L}^{-1}$. In contrast, under $\mathrm{pH} \mathrm{11,} \mathrm{which} \mathrm{could} \mathrm{stimulate}$ the generation of SCOAs using Clostridium (MONOT et al., 1984), Zhang et al. (2005) quantified the following concentrations: $20.5 \mathrm{~g} \mathrm{HLa} \mathrm{L}^{-1}, 8.8 \mathrm{~g} \mathrm{HFo} \mathrm{L}^{-1}$, $13.2 \mathrm{~g} \mathrm{HAc} \mathrm{L}^{-1}, 1.6 \mathrm{~g} \mathrm{HPr} \mathrm{L}^{-1}$ and $4.8 \mathrm{~g} \mathrm{HBu} \mathrm{L}^{-1}$. Taking these data into consideration, comparing to values observed at $16 \mathrm{~h}$ in profiles of Figs. $2 \mathrm{a}$ and $3 \mathrm{~b}$ for reactors $\mathrm{B} 5, \mathrm{~B} 6$ and $\mathrm{B} 7$ (or at $40 \mathrm{~h}$ for reactor $\mathrm{B} 4$ ), for instance, it can be noted there is a certain compatibility between behaviours concerning lactate and acetate, despite they have been generated at considerably higher concentrations by Zhang et al. (2005), which applied a strategy of pH control.

Sydney et al (2014) performed anaerobic digestion batch experiments using sugarcane vinasse as carbon source aiming the production of $\mathrm{H}_{2}$ and SCOAs by applying two bacteria consortia: one from a sample of fruit bat feces (LPB AH1) and another from a sample of a stabilization lake of a dairy farm (LPB AH2). In preliminary tests, utilization of pure vinasse resulted in low biogas production, so supplementation with sugarcane juice, molasse or sucrose was realized in order to stimulate a greater $\mathrm{H}_{2}$ generation. By means of an experimental design to evaluate effects of $\mathrm{pH}$ and carbon source content, it was verified that lactate was the major metabolite in most of runs, especially in those carried out with vinasse supplemented with sugarcane juice at concentrations higher than $10 \mathrm{~g}$ sugar $\mathrm{L}^{-1}$ and using bacteria consortia LPB $\mathrm{AH} 1$.

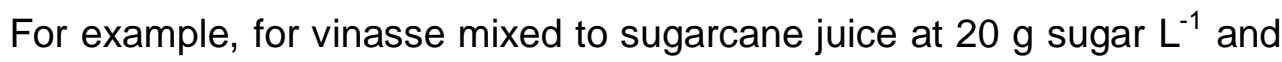
under pH 5.5, Sydney et al. (2014) obtained the following variations in SCOAs contents (generation "+" and consumption "-“): $+8.3 \mathrm{~g} \mathrm{HLa} \mathrm{L}^{-1},+3.2 \mathrm{~g} \mathrm{HFo} \mathrm{L}^{-1}$, +0.7 $\mathrm{g} \mathrm{HAc} \mathrm{L}^{-1}, \quad-0,4 \mathrm{~g} \mathrm{HPr} \mathrm{L}^{-1}$ and $+2.3 \mathrm{~g} \mathrm{HBu} \mathrm{L}^{-1}$, all of them computed through absolute difference taking non-fermented medium as reference. Comparing these data to those of Fig. 2, one can note there is an agreement regarding lactate has been the metabolite produced at higher concentrations, which was observed in reactor B5, B6 and B7 in period 0-32 $\mathrm{h}$ and in reactor B4 in period 0-40 $\mathrm{h}$.

Pursuing generation of $\mathrm{H}_{2}$ in a continuous fermentative reactor system using Enterobacter aerogenes E. 82005 as microorganism and molasse of 


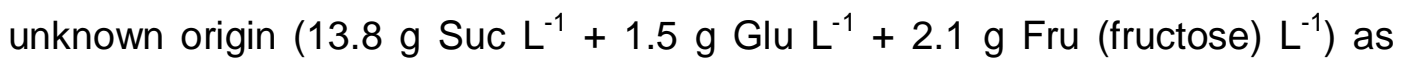
substrate, Tanisho and Ishiwata (1994) obtained lactic acid as the most abundant liquid product, probably by means of a metabolic route similar to the one that seems to have been followed in batch reactors B1-B7 as indicated by profiles of Fig. 2, however not exactly in the same way.

Aiming to evaluate the influence of partial pressure of $\mathrm{H}_{2}$ on SCOAs generation, Zhou et al. (2017) investigated three innovative methods, namely removal of $\mathrm{H}_{2}$ from headspace (T1), aspersion of $\mathrm{CO}_{2}$ (T2) and aspersion of $\mathrm{H}_{2}: \mathrm{CO}_{2}(80: 20)$, besides the typical method, which consisted in not removing $\mathrm{H}_{2}$ as a control test (T4). A glucose solution at $20 \mathrm{~g} \mathrm{Glu} \mathrm{L}^{-1}$ was used as substrate and sludge from a wastewater treatment plant as inoculum for batch reactors. Irrespective of method, lactate was detected as the prevailing metabolite, reaching concentrations of $8.15,9.85,6.63$ e $7.81 \mathrm{~g} \mathrm{HLa} \mathrm{L}^{-1}$ trough methods $\mathrm{T} 1$, T2, T3 e T4, respectively, which is in qualitative accordance with profiles Figs. $2 \mathrm{a}$ and $2 \mathrm{~b}$. However, formiate, which was not obtained in batch experiments of the present work, were obtained by Zhou et al. (2017) in the same way as for Zoetemeyer et al. (1982) while they had studied the effect of $\mathrm{pH}$ on limited concentration glucose solution ( $1 \% \mathrm{Gli})$ acidogenesis.

\subsubsection{Other relevant SCOAs (acetate, propionate, butyrate and isobutyrate) concentrations}

Concerning acetic, propionic and butyric acids, batch reactors have been started under average concentrations near to the ones for these compounds in synthetic vinasse for different values of $\mathrm{COD}_{\text {sol }}$, see Table 2. Particularly for acetic acid, according to Fig. 3a, average initial concentrations were $1.27 \mathrm{~g} \mathrm{HAc}$ $\mathrm{L}^{-1}$ in reactors $\mathrm{B} 1$ and $\mathrm{B} 3,2.09 \mathrm{~g} \mathrm{HAc}^{-1}$ in reactor $\mathrm{B} 2$ and $\mathrm{B} 4$, and $1.67 \mathrm{~g} \mathrm{HAc}$ $\mathrm{L}^{-1}$ in reactors $\mathrm{B} 5, \mathrm{~B} 6$ and $\mathrm{B} 7$.

For reactor B1, as shown in Fig. 3a, there was consumption of acetic acid during the first $8 \mathrm{~h}$ until concentration reaches $0.25 \mathrm{~g} \mathrm{HAc} \mathrm{L}^{-1}$. Differently, in period from $8 \mathrm{~h}$ to $24 \mathrm{~h}$, it was observed an increase up to $0.97 \mathrm{~g} \mathrm{HAc} \mathrm{L}^{-1}$. After an alternation of consumption and generation periods, acetate content decreased to zero at $48 \mathrm{~h}$, however it was once gain detected already at $56 \mathrm{~h}$. Finally, a greater stability of lactate concentration was reached between $56 \mathrm{~h}$ and $72 \mathrm{~h}$ compared to prior incubation time intervals. Also according to Fig. 3a, 
in opposition to what was observed for reactor $\mathrm{B} 1$, reactor $\mathrm{B} 3$ presented a production of acetic acid in the first $8 \mathrm{~h}$ of up to $1.6 \mathrm{~g} \mathrm{HAc} \mathrm{L}^{-1}$. Subsequently, there was prevalence of consumption periods of acetate until $48 \mathrm{~h}$, when a more defined invariability was initiated until $72 \mathrm{~h}$.

In Fig. 3a it is also observed that acetate content in reactor B2 presented a reduction to $0.31 \mathrm{~g} \mathrm{HAc} \mathrm{L}^{-1}$ from $0 \mathrm{~h}$ to $16 \mathrm{~h}$, which was followed by an increase up to $0.64 \mathrm{~g} \mathrm{HAc} \mathrm{L-1}$ at $40 \mathrm{~h}$. Subsequently, there was consumption of acetic acid between $40 \mathrm{~h}$ and $48 \mathrm{~h}$ and finally a greater stability from $48 \mathrm{~h}$ to 72 h. In reactor B4, however, acetate content decreased to $1.2 \mathrm{~g} \mathrm{HAc} \mathrm{L}^{-1}$ in the first $8 \mathrm{~h}$, while an increase to $2.1 \mathrm{~g} \mathrm{HAc} \mathrm{L}^{-1}$ already occurred at $16 \mathrm{~h}$. Period of 16-48 $\mathrm{h}$ was characterized by the intercalation of great consumptions and generations of acetic acid, while period of 48-72 h was of relatively lesser variations. 

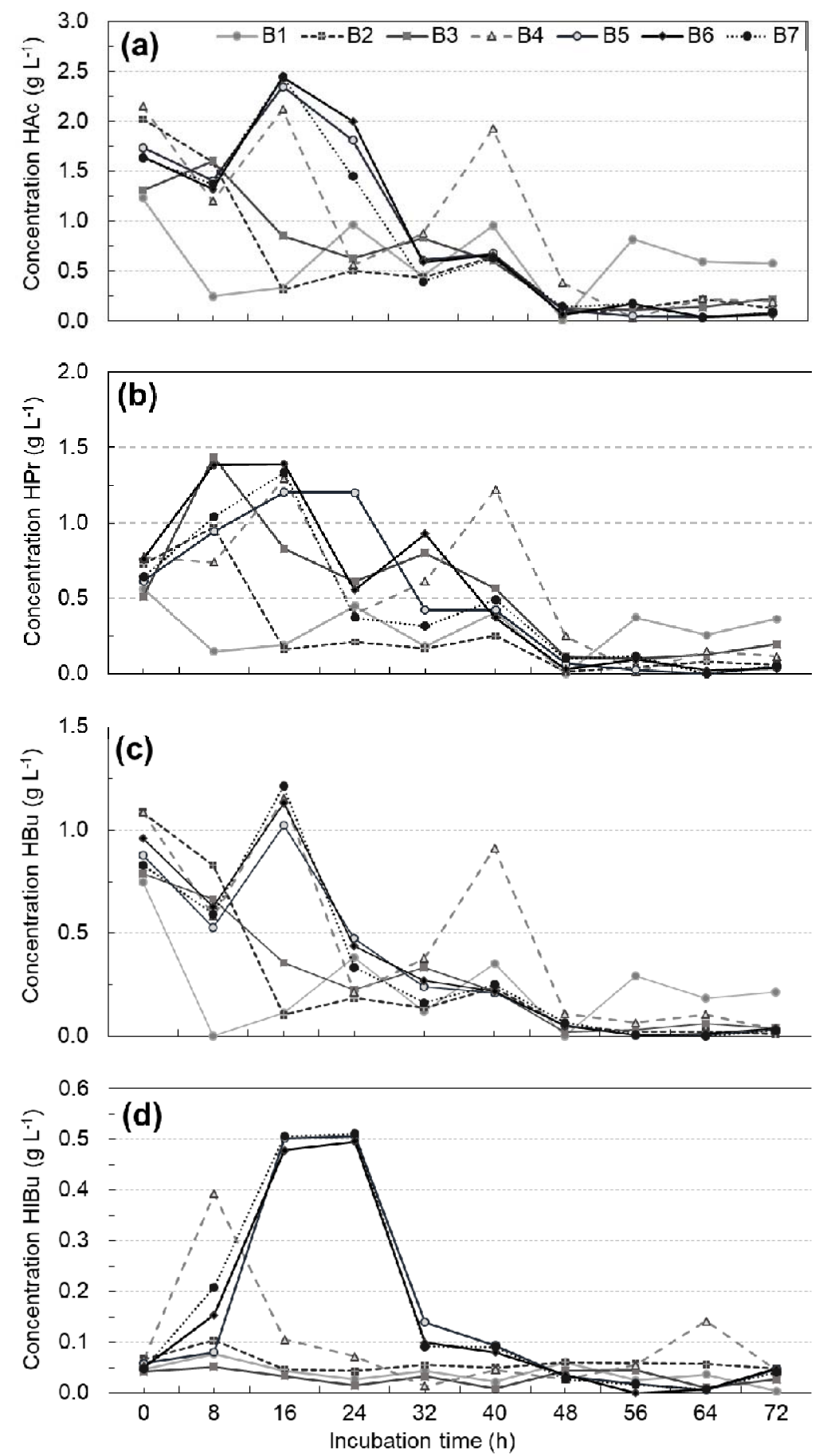

Fig. 2 - Concentration profiles in batch reactors during $72 \mathrm{~h}$ of total operation: (a) acetic acid (HAc), (b) propionic acid (HPr), (c) butyric acid (HBu) and (d) isobutyric acid (HIBu).

Still concerning acetic acid, reactors B5, B6 and B7, starting from identical conditions of $\mathrm{pH}$ and $\mathrm{COD}$, showed concentration profiles qualitatively similar, see Fig. 3a. In all three reactional media there was consumption of acetic acid in period from $0 \mathrm{~h}$ to $8 \mathrm{~h}$, with concentrations attaining 1.40, 1.32 and 
$\mathrm{g} \mathrm{HAc} \mathrm{L}^{-1}$, respectively. In the following incubation times, after peaks have been detected at $16 \mathrm{~h}$, considerable decreases were observed, particularly from $16 \mathrm{~h}$ to 48 h. In a general manner, except for reactor B3, all others exhibited reductions in acetate content until $8 \mathrm{~h}$ and a more or less well established invariability of it from $48 \mathrm{~h}$ to $72 \mathrm{~h}$.

Besides batch anaerobic experiments for SCOAs production, Zhou et al. (2017) have also identified some microorganisms existing in fermentative media and found at least twelve genders, with predominance of Proteus, Enterococcus and Clostridium as the most abundant ones (the two first in methods T1, T2 and T4 and the latter one in method T3). Thus, Zhou et al. (2017) have proposed that methods T1, T2 and T4 caused lactic acid generation by means of microorganisms belonging to Enterobacteriaceae family, which promoted glucose breakdown reaction into metabolites, resulting in 2 ATP. Additionally, for method T4, Zhou et al. (2017) linked the presence of Clostridium to the greater acetate content compared to other methods. Thus, it is possible that some microbial genera detected by Zhou et al. (2017) also existed in the cattle manure sludge utilized in this work since lactate and acetate were both produced in high appreciably concentrations in batch experiments B1-B7.

Concerning propionic acid, operation of reactors were started from the following average concentrations: $0.54 \mathrm{~g} \mathrm{HPr} \mathrm{L}^{-1}$ for reactors $\mathrm{B} 1$ and $\mathrm{B} 3,0.75$ g HPr $L^{-1}$ for reactors $\mathrm{B} 2$ and $\mathrm{B} 4,0.67 \mathrm{~g} \mathrm{HPr} \mathrm{L}^{-1}$ for reactors B5, B6 and B7, as shown in Fig. 3b. Reactors B1 and B3 exhibited a pronounced difference between peaks of propionate concentration, which were $0.45 \mathrm{~g} \mathrm{HPr} \mathrm{L}^{-1}$ at $24 \mathrm{~h}$ and

$\mathrm{g} \mathrm{HPr} \mathrm{L}^{-1}$ at $8 \mathrm{~h}$, respectively. Therefore, reactional medium under higher initial $\mathrm{pH}$ (7.5 for reactor B1, against 4.5 for reactor B3) showed the greatest maximum of propionate content, suggesting that it may be advantageous to carry out acidogenesis at higher initial pH (VENTURA e JAHNG, 2013; HAUS et al., 2011; LI et al., 2014; MONOT et al., 1983; MONOT et al., 1984). In a similar way, reactors $\mathrm{B} 2$ (initial $\mathrm{pH} 4.5$ ) and $\mathrm{B} 4$ (initial $\mathrm{pH} 7.5$ ) reached maximum of propionate content of 0.97 and $1.29 \mathrm{~g} \mathrm{HPr} \mathrm{L}^{-1}$ at $8 \mathrm{~h}$ and $16 \mathrm{~h}$, respectively, without anticipating of greatest concentration peak due to higher initial $\mathrm{pH}$ in 
reactor B4. Additionally, reactors B5, B6 and B7 have attained the greatest propionate concentrations (1.20, 1.39 and $1.34 \mathrm{~g} \mathrm{HPr} \mathrm{L}^{-1}$, respectively).

Isobutyric acid presented similar trends to those for acetic and propionic acids. Thus, reactors under higher initial $\mathrm{pH}$ and same initial COD showed greater peaks of isobutyrate concentration. Moreover, as one can see in Fig. $3 d$, reactors $B 5, B 6$ and $B 7$ presented the highest maximum of isobutyric acid content, which were $0.51,0.50$ and $0.51 \mathrm{~g} \mathrm{HIBu} \mathrm{L}^{-1}$, respectively, all occurring at incubation time $24 \mathrm{~h}$.

Regarding butyric acid, its concentration profiles are shown in Fig. 3c. Its average initial concentrations were $0.77 \mathrm{~g} \mathrm{HBu} \mathrm{L}^{-1}$ for reactors $\mathrm{B} 1$ and $\mathrm{B} 3 ; 1.09$ $\mathrm{g} \mathrm{HBu} \mathrm{L} \mathrm{L}^{-1}$ for reactors $\mathrm{B} 2$ and $\mathrm{B} 4 ; 0.89 \mathrm{~g} \mathrm{HBu} \mathrm{L}^{-1}$ for reactors B5, B6 and B7. Maximum butyrate concentration was $0.38 \mathrm{~g} \mathrm{HBu} \mathrm{L}^{-1}$ at $24 \mathrm{~h}$ in reactor $\mathrm{B} 1$, being lower, however, than the initial content of this compound. In reactor B3, consumption and stability periods were more frequent during batch, excepting the interval 24-32 $\mathrm{h}$, where an increase of $0.11 \mathrm{~g} \mathrm{HBu} \mathrm{L}^{-1}$ was verified, although it was clearly negligible compared to intervals of reductions in butyrate content. In reactors $B 2$ and $B 4$, peaks of butyric acid concentration were 0.24 and 1.16 $\mathrm{g} \mathrm{HBu} \mathrm{L} \mathrm{L}^{-1}$ at incubation times $40 \mathrm{~h}$ and $16 \mathrm{~h}$, respectively. In reactors B5, B6 and B7, maximum of butyric acid concentration were $1.02,1.13$ and $1.21 \mathrm{~g} \mathrm{HBu}$ $\mathrm{L}^{-1}$, respectively, all of them at incubation time $16 \mathrm{~h}$, followed by intervals of consumption and finally of almost invariability.

With the purpose of generating $\mathrm{H}_{2}$, Fang et al. (2006) carried out fermentation batch experiments of rice slurry as carbon source and sludge from a municipal sewage treatment plant as mixed culture of microorganisms (thermally pre-treated at $100{ }^{\circ} \mathrm{C}$ for $30 \mathrm{~min}$ ). Effects of $\mathrm{pH}$, temperature and carbohydrate (Carb) concentration were assessed. Particularly, evaluation of influence of carbohydrate concentration (2.7-22.1 g Carb $\mathrm{L}^{-1}, \mathrm{pH} 4.5$ and temperature $37{ }^{\circ} \mathrm{C}$ ) showed that acetic and butyric acids were the major metabolites, while methanol, propanol, propionic, valeric acid (HVa) and caproic acid $(\mathrm{HCa})$ were also detected, but at relatively lower contents. For example,

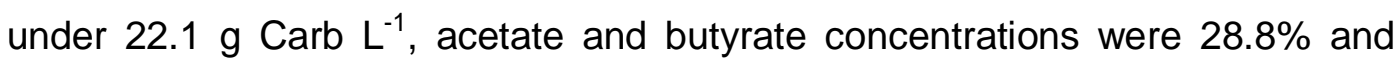
$70.9 \%$ out of $\sim 10.6 \mathrm{~g}$ total SCOAs + alcohols $\mathrm{L}^{-1}$. 
An important aspect approached by Fang et al. (2006) was the identification of microorganisms, which indicated a greater abundance of Clostridium bacteria genus of strictly anaerobic class in sludge. A number of acidogenic species able to produce $\mathrm{H}_{2}$ were found, such as $C$. acetobutylicum, C. butylicum, C. pasteurianum, etc., that might as well be present in the cattle manure sludge used in this work, although it cannot be assertively stated based only on profiles of batch reactors B1-B7. Nonetheless, since final reactional medium obtained by Fang et al. (2006) contained mainly acetate, butyrate and small amounts of alcohols (besides other minority acids), it is observed disagreement with profiles depicted in Figs. 2 and 3, indicating that distinct routes were followed, which can certainly be associated to different conditions defined for sets of experiments of each work.

Zong et al. (2009) executed a process consisting of consecutive dark fermentation and photofermentation in batch mode and using cassava wastewater (18 $\mathrm{g}$ hexose $\left.\mathrm{L}^{-1}\right)$, food wastes from coffee shop (20 $\left.\mathrm{g} \mathrm{L}^{-1}\right)$ and sucrose $\left(18 \mathrm{~g} \mathrm{~L}^{-1}\right.$ ) as carbon sources plus several minerals for composing reactional medium. It is important to note that effluent of dark fermentation was centrifuged and diluted and had its $\mathrm{pH}$ adjusted to 7.0 in order to be subsequently processed by photofermentation. A cattle manure compound was applied as inoculum in dark fermentation and isolated cells of Rhodobacter sphareoides ZX-5 in photofermentation.

Focus of Zong et al. (2009) was the production of $\mathrm{H}_{2}$, which was obtained simultaneously to the generation of SCOAs such as acetate, propionate, butyrate and isobutyrate. For instance, fixing initial pH 6.8 (no control), experiment using coffee shop wastes processed by means of dark fermentation provided contents of $2.54 \mathrm{~g} \mathrm{HAc} \mathrm{L}^{-1}, 0.37 \mathrm{~g} \mathrm{HPr} \mathrm{L}^{-1}, 5.46 \mathrm{~g} \mathrm{HBu} \mathrm{L}^{-1}, 0.88 \mathrm{~g} \mathrm{HIBu}$ $\mathrm{L}^{-1}$, attaining final $\mathrm{pH}$ 4.84. In the same experiment, butanol was obtained at $1.26 \mathrm{~g} \mathrm{BuOH} \mathrm{L}^{-1}$. So, although at lower concentrations, all acidic metabolites detected by Zong et al. (2009) were also verified in batch tests of this work, as can be seen in profiles showed in Figs. 2 and 3, while butanol were not produced. This does not exclude definitely the possibility of existence of microorganisms producing butyl alcohol in cattle manure sludge used in 
reactors $\mathrm{B} 1-\mathrm{B} 7$, however indicates clearly that at least they were not effective to convert substrate in solvent.

By means of batch experiments, Silva et al. (2013) evaluated anaerobic acidification of eight different organic materials, namely cheese whey, sugarcane molasse, organic fraction of municipal solid wastes, glycerol, soapy slurry, winery wastewater, olive mill effluent and landfill leachate. Sludge from a treatment plant for domestic and industrial effluents was used as inoculum. Particularly, cheese whey $\left(\mathrm{COD}_{\text {sol }} 98 \mathrm{~g} \mathrm{~L}^{-1}\right)$, sugarcane molasse $\left(\mathrm{COD}_{\text {sol }} 896 \mathrm{~g}\right.$ $\left.\mathrm{L}^{-1}\right)$ and organic fraction of municipal solid wastes $\left(\mathrm{COD}_{\text {total }} 30 \mathrm{~g} \mathrm{~L}^{-1}\right)$ showed the greatest acidogenic potential, producing 0.33-0.42 g SCOAs (g COD feed) ${ }^{-1}$, with prevalence of acetic, butyric and propionic acids, which were also obtained in batch reactors of the presented work, see Fig. 3, even though they were not the major metabolites in ascending order. However, by varying the proportion substrate/microorganism and alkalinity of medium through addition of $\mathrm{CaCO}_{3}$, Silva et al. (2013) were able to increase production up to $0.63 \mathrm{~g}$ total SCOAs ( $\mathrm{g}$ COD feed $)^{-1}$, shifting the content predominance to propionic and valeric acids.

Davila-Vazquez et al. (2011) performed batch experiments with cheese

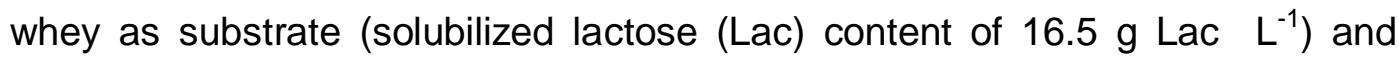
sludge from an UASB reactor for treatment of candy factory wastewater as inoculum. Carbonate- and phosphate-based buffering media were employed in order to reduce $\mathrm{pH}$ variations. In tests with carbonate-based buffer carried out in a $3 \mathrm{~L}$ fermenter, concentrations of $2.3 \mathrm{~g} \mathrm{HAc} \mathrm{L}^{-1}, 3.4 \mathrm{~g} \mathrm{HPr} \mathrm{L}^{-1}, 5.0 \mathrm{~g} \mathrm{HBu} \mathrm{L}^{-1}$ and $0.08 \mathrm{~g} \mathrm{EtOH}$ (ethanol) $\mathrm{L}^{-1}$ were attained through a carbohydrate consumption $>99 \%$ of available lactose, greater than that in batch reactors of the present work shown in Fig. 1a.

Using a substrate containing lactose (same monosaccharide of cheese whey), Collet et al. (2003) observed the presence of lactate in medium resulting from batch fermentation with Clostridium thermolactitum. However, opposing to this observation, Davila-Vazquez et al. (2011) did not obtained lactate, which probably occurred due to the absence of microorganisms promoting lactic fermentation in mixed culture used as inoculum. Moreover, by comparing results presented here to those by Davila-Vazquez et al. (2011), once again one can see quantitative disagreement since ascending order of metabolites 
concentrations for both works are distinct, even though most of acids produced are common (excepting lactate and isobutyrate).

Additionally, Davila-Vazquez et al. (2011) also carried out analyses of microbial communities that have developed in $120 \mathrm{~cm}^{3}$ vials containing buffering mineral media. Under the evaluated conditions, results are suggestive of existence of bacteria from Clostridium and Enterobacter genera, known as efficient $\mathrm{H}_{2}$ producers. In this sense, in batch experiments using xylose and cellulose as substrates separately, Lin and Hung (2008) have found microorganisms from Klebsiella, Pseudomonas, Clostridium and Streptococcus genera in cattle manure sludge. Therefore, despite the similarity of origin of inocula used in Lin and Hung (2008) and in this work (note that specific cattle kind and and it its food diet are also relevant factors), Lin and Hung (2008) have detected other major metabolites, namely $\mathrm{H}_{2}$, ethanol, acetic acid, propionic acid and butyric acid.

\subsection{Maxima of SCOAs productivities}

Acidogenesis profiles for batch reactors B1-B7 pointed out that metabolites presenting the highest concentration peaks were lactic, propionic, acetic and isobutyric acids in ascending order. Maxima of productivities of these compounds occurred at specific incubation times and are shown in Table 4. Among all acidic products, lactate exhibited the greatest peak of productivity, observed in reactor $\mathrm{B} 3$ at $8 \mathrm{~h}$, which was $332.10 \mathrm{mg} \mathrm{HLa} \mathrm{L}^{-1} \mathrm{~h}^{-1}$. However, at

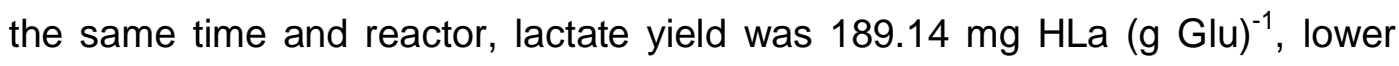
than those calculated for some other batch reactors, indicating that maximum of both performance parameters were not verified simultaneously for lactic acid.

Reactors B5, B6 and B7, all prepared under identical initial $\mathrm{pH}$ and $\mathrm{COD}$, presented maximum of lactic acid productivity at $16 \mathrm{~h}$, although value obtained for this parameter was slightly higher for reactor B7 (309.88 $\mathrm{mg} \mathrm{HLa} \mathrm{L}^{-1} \mathrm{~h}^{-1}$ ). Since incubation time of $0 \mathrm{~h}$ (starting point for experiments) was taken as a reference to compute $P$ and $Y$, see Eqs. (1) and (2), a similar trend to that for productivities applies for yields in reactors B5, B6 and B7 as well, with a very small advantage for reactor B7, which presented a little bit higher maximum of

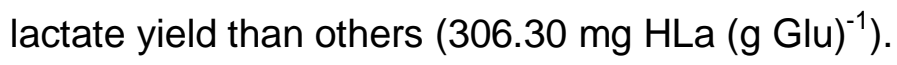


In all batch reactors (B1-B7), peaks of productivity and corresponding yields of lactic acid were expressively greater than those of other metabolites. Invariably, as shown in Table 4, the highest maximum of productivity for propionate, acetate and isobutyrate were observed at incubation times of $8 \mathrm{~h}$ and $16 \mathrm{~h}$. For propionic acid, maximum of productivity was $115.28 \mathrm{mg} \mathrm{HPr} \mathrm{L}^{-1} \mathrm{~h}^{-}$ 1 at $8 \mathrm{~h}$, with a simultaneous yield of $65.65 \mathrm{mg} \mathrm{HPr} \mathrm{(g} \mathrm{Glu})^{-1}$. For acetic and isobutyric acids, maximum of productivity and yield were limited up to about 50 $\mathrm{g} \mathrm{L}^{-1} \mathrm{~h}^{-1}$ and $50 \mathrm{mg}(\mathrm{g} \mathrm{Glu})^{-1}$.

By means of anaerobic digestion batch experiments also employing cattle manure sludge as inoculum, Moraes et al. (2019) obtained considerably high concentrations of lactic acid mainly when using a mixture of real vinasse and a synthetic culture medium at $1: 3 \mathrm{v} / \mathrm{v}$. Actually, lactate was the major metabolite in these specific tests, regardless of pre-treatment method applied to sludge. However, tests performed under higher contents of real vinasse in mixture, particularly at $2: 1 \mathrm{v} / \mathrm{v}$, showed profiles indicating there was consumption of lactate in certain incubation periods. Additionally, in the same way as Lappa et al. (2015b), Moraes et al. (2019) linked the increase in butyrate concentration to the reduction of lactate concentration.

Despite of Moraes et al. (2019) have not presented lactic acid productivities and yields probably because lactate was not taken as a product of interest of acidogenesis, concentrations and incubation times were given, namely a maximum of $8.8 \mathrm{~g} \mathrm{HLa} \mathrm{L}^{-1}$ at $144 \mathrm{~h}$ (6 days) from an initial

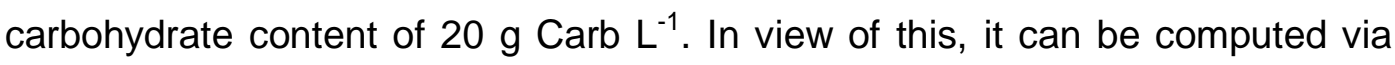
Eq. (1) that peak of productivity was $61.1 \mathrm{~g} \mathrm{HLa} \mathrm{L}^{-1} \mathrm{~h}^{-1}$, resulting in a yield 440.0 $\mathrm{mg} \mathrm{HLa} \mathrm{(g} \mathrm{Carb)})^{-1}$ by Eq. (2). Both values of parameters were verified at $1: 3 \mathrm{v} / \mathrm{v}$ with sludge being pre-treated by acidic + thermal method. By comparing these results to those shown in Table 4, one can presume that lower incubation time associated to maximum of productivity of present work $\left(8 \mathrm{~h}, 332.10 \mathrm{~g} \mathrm{HLa} \mathrm{L}^{-1} \mathrm{~h}^{-}\right.$ ${ }^{1}$ ) is the cause of difference.

Using vinasse as substrate, Djukić-Vuković et al. (2015) conducted lactic fermentation experiments in presence of Lactobacillus rhamnosus ATCC 7469 strain and have attained a maximum of $50.18 \mathrm{~g} \mathrm{HLa} \mathrm{L}^{-1}$ for lactate concentration, resulting in a corresponding productivity of $1480 \mathrm{mg} \mathrm{HLa} \mathrm{L}^{-1} \mathrm{~h}^{-1}$ 
and a yield of $900 \mathrm{mg} \mathrm{HLa} \mathrm{(g} \mathrm{Carb)}{ }^{-1}$. Comparing them to those listed in Table 4, the greatest values of performance parameters obtained by Djukić-Vuković et al. (2015) are certainly due to use of a Lactobacillus species, highly specialized in producing lactate, as fermentative microorganism instead of a mixed culture containing a wide microbial diversity, which was the case of present work.

Using vinasse as nutrient source and cells of Lactobacillus rhamnosus ATCC 7469 fixed over zeolite particles as inoculum, Djukić-Vuković et al. (2013) attained a maximum of $42.19 \mathrm{~g} \mathrm{HLa} \mathrm{L-1}$ for lactate content, with a correspondent productivity of $1690 \mathrm{~g} \mathrm{HLa} \mathrm{L}^{-1} \mathrm{~h}^{-1}$ and yield of $960 \mathrm{~g} \mathrm{HLa} \mathrm{L}^{-1}$. Employing the same microorganism, but this time deposited on the surface of Mg-modified zeolite particles, Djukić-Vuković et al. (2016) reached maximum of $47.60 \mathrm{~g} \mathrm{HLa} \mathrm{L}^{-1}$ (lactate content), $1410 \mathrm{mg} \mathrm{HLa} \mathrm{L}^{-1} \mathrm{~h}^{-1}$ (lactate productivity) and $860 \mathrm{~g} \mathrm{HLa} \mathrm{L}^{-1}$ (lactate yield). Taking into consideration both these previous studies, lactate concentration and performance parameters were higher than those detected in the present work because carbohydrate content in substrate was notably greater, $50 \mathrm{~g}$ Carb L ${ }^{-1}$ (DJUKIĆ-VUKOVIĆ et al., 2013; DJUKIĆVUKOVIĆ et al., 2016), compared to a maximum concentration of $18 \mathrm{~g} \mathrm{Glu} \mathrm{L}^{-1}$ adopted for synthetic vinasse in batch experiments B1-B7. Moreover, Lactobacillus rhamnosus ATCC 7469 is surely more suitable for lactic acid generation than cattle manure sludge utilized here. 
Table 4 - Maxima of productivities and corresponding yields for major metabolites generated in synthetic vinasse acidogenesis for all batch reactors.

\begin{tabular}{|c|c|c|c|c|c|c|c|c|c|c|c|c|}
\hline \multirow{2}{*}{$\begin{array}{l}\text { Batch } \\
\text { reactor }\end{array}$} & $\begin{array}{l}\text { Incubation } \\
\text { time }\end{array}$ & \multicolumn{2}{|c|}{$\begin{array}{c}\text { Lactic acid } \\
\quad(\mathrm{HLa})\end{array}$} & $\begin{array}{l}\text { Incubation } \\
\text { time }\end{array}$ & \multicolumn{2}{|c|}{$\begin{array}{c}\text { Propionic acid } \\
\text { (HPr) }\end{array}$} & $\begin{array}{l}\text { Incubation } \\
\text { time }\end{array}$ & \multicolumn{2}{|c|}{$\begin{array}{c}\text { Acetic acid } \\
\text { (HAc) }\end{array}$} & $\begin{array}{l}\text { Incubation } \\
\text { time }\end{array}$ & \multicolumn{2}{|c|}{$\begin{array}{c}\text { Isobutyric acid } \\
(\mathrm{HIBu})\end{array}$} \\
\hline & $\mathrm{h}$ & $\mathrm{mg} \mathrm{L}^{-1} \mathrm{~h}^{-1}$ & $\mathrm{mg}\left(\mathrm{g} \mathrm{Suc}^{-1}\right)$ & $\mathrm{h}$ & $\mathrm{mg} \mathrm{L}^{-1} \mathrm{~h}^{-1}$ & $\mathrm{mg}\left(\mathrm{g} \mathrm{Suc}^{-1}\right)$ & $\mathrm{h}$ & $\mathrm{mg} \mathrm{L}^{-1} \mathrm{~h}^{-1}$ & $\mathrm{mg}\left(\mathrm{g} \mathrm{Suc}^{-1}\right)$ & $\mathrm{h}$ & $\mathrm{mg} \mathrm{L}^{-1} \mathrm{~h}^{-1}$ & $\mathrm{mg}\left(\mathrm{g}\right.$ Suc $\left.\mathrm{c}^{-1}\right)$ \\
\hline B2 & 40 & 70.40 & 146.81 & 8 & 30.30 & 12.64 & - & - & - & 8 & 4.63 & 1.93 \\
\hline B3 & 8 & 332.10 & 189.14 & 8 & 115.28 & 65.65 & 8 & 36.39 & 20.72 & 8 & 1.20 & 0.69 \\
\hline B6 & 16 & 291.54 & 299.77 & 8 & 77.58 & 39.88 & 16 & 49.74 & 51.15 & 16 & 26.70 & 27.45 \\
\hline B7 & 16 & 309.88 & 306.30 & 8 & 49.37 & 24.40 & 16 & 50.84 & 50.25 & 16 & 28.65 & 28.32 \\
\hline
\end{tabular}

Labels: *symbol "-" indicates there was consumption of metabolite during operation of batch reactor regarding initial value of concentration (incubation time 0 h). 


\subsection{Possible biogas generation and process mass balance}

Anaerobic digestion performed by mixed cultures of bacteria is certainly one of the most common ways of producing SCOAs from a great number of substrates, with emphasis on residual materials. In many cases, however, the goal of acidogenic anaerobic digestion is not exactly the generation of SCOAs, which presents a wide range of applications, but the generation of biogas since chemical reactions resulting in butyric and acetic acids from a carbon source also results in $\mathrm{H}_{2}$, a compound with interesting properties for use as gaseous fuel. These reactions are shown in Eqs. (6) and (7) for glucose, a directly fermentable sugar, as substrate.

$$
\begin{array}{ll}
\mathrm{C}_{6} \mathrm{H}_{12} \mathrm{O}_{6} \rightarrow \underbrace{\mathrm{CH}_{3} \mathrm{CH}_{2} \mathrm{CH}_{2} \mathrm{COOH}}_{\text {butyric acid }}+2 \mathrm{CO}_{2}+2 \mathrm{H}_{2} & \Delta \mathrm{G}^{0}=-253,50 \mathrm{~kJ} \mathrm{~mol}^{-1} \\
\mathrm{C}_{6} \mathrm{H}_{12} \mathrm{O}_{6}+2 \mathrm{H}_{2} \mathrm{O} \rightarrow 2 \underbrace{\mathrm{CH}_{3} \mathrm{COOH}}_{\text {acetic acid }}+2 \mathrm{CO}_{2}+4 \mathrm{H}_{2} & \Delta \mathrm{G}^{0}=-191,64 \mathrm{~kJ} \mathrm{~mol}^{-1}
\end{array}
$$

In chemical reactions producing lactic and propionic acids (both metabolites that can also be relevant in acidogenesis depending on conditions it is performed) from glucose, see Eqs. (8) and (9), one can note there is no formation of $\mathrm{CO}_{2}$ and $\mathrm{H}_{2}$, which differs clearly from what is observed in Eqs. (6) and (7). In contrast, as show in Eq. (9), actually there is consumption instead of generation of $\mathrm{H}_{2}$ in reaction providing propionic acid.

$$
\begin{array}{ll}
\mathrm{C}_{6} \mathrm{H}_{12} \mathrm{O}_{6} \rightarrow 2 \underbrace{\mathrm{CH}_{3} \mathrm{CHOHCOOH}}_{\text {lactic acid }} & \Delta \mathrm{G}^{0}=-146,70 \mathrm{~kJ} \mathrm{~mol}^{-1} \\
\mathrm{C}_{6} \mathrm{H}_{12} \mathrm{O}_{6}+2 \mathrm{H}_{2} \rightarrow 2 \underbrace{\mathrm{CH}_{3} \mathrm{CH}_{2} \mathrm{COOH}}_{\text {propionic acid }}+2 \mathrm{H}_{2} \mathrm{O} & \Delta \mathrm{G}^{0}=-338,50 \mathrm{~kJ} \mathrm{~mol}^{-1}
\end{array}
$$

So, even though productive purposes are distinct, it is appropriate to realize comparisons of results of present work, obtained through experiments aiming to generate SCOAs, to results from previous works that focused on biogas production, mainly $\mathrm{H}_{2}$. In view of this, results from technical literature and also results of some of batch experiments B1-B7 are reunited in Table 5. Based on them, the most notable observations one can do are the following: absence of lactic acid in majority of fermentative media and prevalence of acetic and butyric acids (the two most common in acidogenesis) in a wide number of references. Additionally, it is important to highlight that ethanol, already existing 
in original synthetic vinasse at different $\mathrm{COD}_{\text {sol, }}$ did not show significant content variations in tests with cattle manure sludge of the present work.

It should be emphasized that synthesis reactions of SCOAs, Eqs. (6)-(9), are exergonic since variations of free Gibbs energy for them, estimated by means of e-Quilibrator tool (FLAMHOLZ et al., 2011), are all negative. So, these are spontaneous processes, although their degrees of spontaneity are different from each other. Moreover, trends showed in Figs. 2 and 3 sometimes are not in accordance to some cause and effect relationships found in technical literature for process monitoring parameters and concentrations of SCOAs. However, this would be expected because several factors interfering in experimental results were not measured or controlled. In this sense, besides direct comparisons to other works are difficult due to different operating conditions, identification of microorganisms existing in cattle manure sludge would allow a clearer understanding of causes, which however was not carried out in present work. Despite of it, trends verified are useful in some ways, even as preliminary results, mainly to indicate directions favouring production of interest metabolites, although these directions are not definitive.

In profiles showed in Figs. 2 and 3, intervals near to the end of batch experiments are remarkable, particularly after $48 \mathrm{~h}$, when concentrations of SCOAs in most of reactors were notably low, showing periods of consumption of these metabolites. A reasonable explanation for this behaviour seems to be the generation of $\mathrm{H}_{2}$, carbon dioxide $\left(\mathrm{CO}_{2}\right)$ and $\mathrm{CH}_{4}$, the latter certainly at lower amount. All of them are gaseous products probably generated by microbe existing in cattle manure sludge, but that have not been identified or quantified. Therefore, acidic + thermal pre-treatment may not have been effective to eliminate completely the methanogenic archaeas and these microorganisms may have been developed, even in an incipient way, and performed intensively in periods where contents of acids were decreased, since this is an indication of methanogenesis occurrence. In contrast, for periods where acids contents were increased, acting of SCOAs-producing bacteria, which also generate $\mathrm{H}_{2}$ and $\mathrm{CO}_{2}$, see Eqs. (8) and (9), was surely more pronounced. In fact, in batch experiments of this work, gas production was verified empirically. 
bioRxiv preprint doi: https://doi.org/10.1101/2021.02.22.432232; this version posted February $23,2021$. The copyright holder for this preprint

(which was not certified by peer review) is the author/funder, who has granted bioRxiv a license to display the preprint in perpetuity. It is made available under aCC-BY-NC-ND 4.0 International license.

Table 5 - Concentrations of major SCOAs generated by means of acidogenic fermentation in batch reactors with a diversity of substrates and mixed cultures from different origins.

\begin{tabular}{|c|c|c|c|c|c|c|c|}
\hline \multirow{2}{*}{ Substrate } & \multirow{2}{*}{ Mixed culture } & \multirow{2}{*}{ pH } & \multicolumn{4}{|c|}{ Concentration (g SCOA L ${ }^{-1}$ ) } & \multirow{2}{*}{ Reference } \\
\hline & & & $\mathrm{HBu}$ & HAc & HLa & HPr & \\
\hline $\begin{array}{l}\text { Food waste } \\
\left(53.18 \mathrm{~g} \mathrm{COD}_{\text {sol }} \mathrm{L}^{-1}\right)\end{array}$ & $\begin{array}{l}\text { Microorganisms } \\
\text { existing in original } \\
\text { substrate }\end{array}$ & $\begin{array}{c}5.5 \\
\text { (controlled) }\end{array}$ & 18.5 & 1.0 & 14.9 & 4.5 & $\begin{array}{l}\text { Zhang et al. } \\
\qquad(2005)\end{array}$ \\
\hline $\begin{array}{l}\text { Rice slurry } \\
\left(22.1 \mathrm{~g} \mathrm{Carb} \mathrm{L}^{-1}\right)^{*}\end{array}$ & $\begin{array}{l}\text { Sludge from a } \\
\text { municipal sewage } \\
\text { treatment plant }\end{array}$ & $\begin{array}{c}4.5 \\
\text { (controlled) }\end{array}$ & 7.5 & 3.0 & $\mathrm{NA}^{+}$ & NA & $\begin{array}{l}\text { Fang et al. } \\
\text { (2006) }\end{array}$ \\
\hline 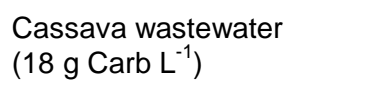 & $\begin{array}{l}\text { Cattle dung compost } \\
\text { (dark fermentation) }\end{array}$ & $\begin{array}{l}6.8 \text { (initial) } \\
4.8 \text { (final) }\end{array}$ & 4.3 & 2.2 & NA & 0.4 & $\begin{array}{l}\text { Zong et al. } \\
\text { (2009) }\end{array}$ \\
\hline $\begin{array}{l}\text { Sucrose } \\
\left(18 \mathrm{~g} \mathrm{Carb} \mathrm{L}^{-1}\right)\end{array}$ & $\begin{array}{l}\text { Cattle dung compost } \\
\text { (dark fermentation) }\end{array}$ & $\begin{array}{l}6.8 \text { (initial) } \\
4.8 \text { (final) }\end{array}$ & 5.1 & 2.1 & NA & 0.2 & $\begin{array}{l}\text { Zong et al. } \\
\quad(2009)\end{array}$ \\
\hline $\begin{array}{l}\text { Cheese whey } \\
\text { (with a carbonate-based } \\
\text { buffering medium) } \\
\left(16.5 \mathrm{~g} \mathrm{Lac} \mathrm{L}^{-1}\right)\end{array}$ & $\begin{array}{l}\text { Sludge from a UASB } \\
\text { reactor for treatment } \\
\text { of candy factory } \\
\text { wastewater }\end{array}$ & $\begin{array}{l}7.5 \text { (initial) } \\
5.4 \text { (final) }\end{array}$ & 5.0 & 2.3 & NA & 3.4 & $\begin{array}{l}\text { Davila- } \\
\text { Vazquez et al. } \\
\quad(2011)\end{array}$ \\
\hline $\begin{array}{l}\text { Cheese whey } \\
\text { (with a phosphate-based } \\
\text { buffering medium) } \\
\left(16.5 \mathrm{~g} \mathrm{Lac} \mathrm{L}^{-1}\right)\end{array}$ & $\begin{array}{l}\text { Sludge from a UASB } \\
\text { reactor for treatment } \\
\text { of candy factory } \\
\text { wastewater }\end{array}$ & $\begin{array}{l}7.5 \text { (initial) } \\
4.9 \text { (final) }\end{array}$ & 1.8 & 1.1 & NA & 2.1 & $\begin{array}{l}\text { Davila- } \\
\text { Vazquez et al. } \\
\quad(2011)\end{array}$ \\
\hline 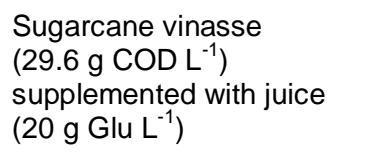 & $\begin{array}{l}\text { Sample of fruit bat } \\
\text { feces }\end{array}$ & 5.5 (final) & +2.3 & +0.8 & +8.3 & -0.4 & $\begin{array}{l}\text { Sydney et al. } \\
\qquad(2014)^{\star \star}\end{array}$ \\
\hline $\begin{array}{l}\text { Sugarcane vinasse } \\
\left(29.6 \mathrm{~g} \mathrm{COD} \mathrm{L}^{-1}\right) \\
\text { supplemented with molasse } \\
\left(20 \mathrm{~g} \mathrm{Glu} \mathrm{L}^{-1}\right)\end{array}$ & $\begin{array}{l}\text { Sample from a } \\
\text { (stabilization) lake of } \\
\text { a dairy farm }\end{array}$ & 5.5 (final) & +3.7 & -0.6 & 0.0 & -0.7 & $\begin{array}{l}\text { Sydney et al. } \\
(2014)^{\star \star}\end{array}$ \\
\hline $\begin{array}{l}\text { Cheese whey } \\
\left(98 \mathrm{~g} \mathrm{COD}_{\text {sol }} \mathrm{L}^{-1}\right)\end{array}$ & $\begin{array}{l}\text { Sludge from a } \\
\text { treatment plant for } \\
\text { domestic and } \\
\text { industrial effluents }\end{array}$ & 6.35 (initial) & $\sim 0.87$ & $\sim 1.67$ & NA & $\sim 0.24$ & $\begin{array}{l}\text { Silva et al. } \\
(2013)^{\star * *}\end{array}$ \\
\hline $\begin{array}{l}\text { Sugarcane molasse } \\
\left(896 \mathrm{~g} \mathrm{COD}_{\text {sol }} \mathrm{L}^{-1}\right)\end{array}$ & $\begin{array}{l}\text { Sludge from a } \\
\text { treatment plant for } \\
\text { domestic and } \\
\text { industrial effluents }\end{array}$ & 5.83 (initial) & $\sim 0.41$ & $\sim 1.60$ & NA & $\sim 0.27$ & $\begin{array}{l}\text { Silva et al. } \\
(2013)^{\star \star \star}\end{array}$ \\
\hline $\begin{array}{l}\text { Glucose solution } \\
\left(20 \mathrm{~g} \mathrm{Glu}^{-1}\right) \\
\text { (T2, with } \mathrm{CO}_{2} \text { aspersion) }\end{array}$ & $\begin{array}{l}\text { Sludge from a } \\
\text { wastewater } \\
\text { treatment plant }\end{array}$ & $\begin{array}{l}\sim 6.60 \text { (initial) } \\
\sim 4.15 \text { (final) }\end{array}$ & NA & $\sim 0.37$ & 9.85 & $\sim 0.10$ & $\begin{array}{l}\text { Zhou et al. } \\
(2017)^{\star \star \star}\end{array}$ \\
\hline $\begin{array}{l}\text { Synthetic vinasse } \\
\left(20 \mathrm{~g} \mathrm{COD} \mathrm{L}^{-1}\right) \\
\text { (reactor } \mathrm{B} 1)\end{array}$ & $\begin{array}{l}\text { Cattle manure } \\
\text { sludge }\end{array}$ & $\begin{array}{l}4.5 \text { (initial) } \\
4.2 \text { (final) }\end{array}$ & 0.38 & 0.97 & $\begin{array}{l}2.71 \\
(24 \mathrm{~h})\end{array}$ & 0.45 & $\begin{array}{l}\text { Present } \\
\text { work }^{\S}\end{array}$ \\
\hline $\begin{array}{l}\text { Synthetic vinasse } \\
\left(25 \mathrm{~g} \mathrm{COD} \mathrm{L}^{-1}\right) \\
\text { (reactor } \mathrm{B} 7)\end{array}$ & $\begin{array}{l}\text { Cattle manure } \\
\text { sludge }\end{array}$ & $\begin{array}{l}6.0 \text { (initial) } \\
4.8 \text { (final) }\end{array}$ & 1.21 & 2.45 & $\begin{array}{l}4.96 \\
(16 \mathrm{~h})\end{array}$ & 1.34 & $\begin{array}{l}\text { Present } \\
\text { work }^{\S}\end{array}$ \\
\hline $\begin{array}{l}\text { Synthetic vinasse } \\
\left(30 \mathrm{~g} \mathrm{COD} \mathrm{L}^{-1}\right) \\
\text { (reactor } \mathrm{B} 4)\end{array}$ & $\begin{array}{l}\text { Cattle manure } \\
\text { sludge }\end{array}$ & $\begin{array}{l}7.5 \text { (initial) } \\
4.8 \text { (final) }\end{array}$ & 0.91 & 1.93 & $\begin{array}{l}4.77 \\
(40 \mathrm{~h})\end{array}$ & 1.22 & $\begin{array}{l}\text { Present } \\
\text { work }^{\S}\end{array}$ \\
\hline
\end{tabular}

Labels: NA*: not available or not detected; *Higher concentration of substrate adopted by Fang et al. (2006); **Presented generation (+) and consumption (-) taking the blank as reference, however did not give concentrations of SCOAs in non-fermented media (blank); ${ }^{* *}$ Concentrations preceded by the symbol " " were extracted from graphics, so they are approximations; ${ }^{\S}$ Parameters verified at the incubation time of maximum concentration of lactate. 
Similarly to results presented here, for anaerobic digestion processes of $1 G$ and $2 G$ (first and second generation) vinasses with sludge from a UASB reactor degrading $1 \mathrm{G}$ vinasse, Silverio et al. (2019) verified the alternation of periods of generation and consumption of acids throughout feed batch experiments. For periods of accumulation of acids, acetogenic bacteria and hidrogenotrophic and acetoclastic archaeas surely presented small activity (SILVERIO et al., 2019). On the other hand, for periods in which there were reductions of acids concentrations, it is reasonable that the opposite justification is valid (MOSEY, 1982; SILVERIO et al., 2019). These arguments provide some support to the hypothesis that there was $\mathrm{CH}_{4}$ generation in experiments with cattle manure sludge of the present work, although a more categorical evidence is lacking, especially because of acidic + thermal pre-treatment that was performed to inoculum.

Finally, mass balances at $72 \mathrm{~h}$ (final incubation time) for all batch reactors are presented in Table 5 and reveals poor agreement between total theoretical and experimental CODs (35-60\%), suggesting there were indeed other products in reactional media which were not accounted for. Therefore, it is probable that production of unidentified liquid and dissolved gaseous metabolites has occurred in experiments conducted in this work for assessment of initial $\mathrm{pH}$ and COD of synthetic vinasse (PEIXOTO et al., 2012; AMORIM et al., 2014; MARTINS AND AMORIM, 2016). This could be taken as a consequence of using cattle manure sludge since it certainly contains a number of different microbes capable of generating several compounds undetected as fermentative products. 
Table 6 - Mass balance in terms of COD at $72 \mathrm{~h}$ for all batch reactors.

\begin{tabular}{|c|c|c|c|c|c|c|c|}
\hline \multirow{2}{*}{$\begin{array}{c}\text { COD } \\
\left(10^{-3} \mathrm{~g} \mathrm{~L}^{-1}\right)\end{array}$} & \multicolumn{7}{|c|}{ Batch reactors } \\
\hline & B1 & B2 & B3 & B4 & B5 & B6 & B7 \\
\hline $\mathrm{HMa}$ & 54.72 & 47.17 & 53.75 & 48.42 & 63.62 & 61.42 & 60.49 \\
\hline HSu & 32.97 & 22.82 & 31.15 & 28.19 & 16.08 & 14.69 & 17.88 \\
\hline HLa & 1376.16 & 345.37 & 344.14 & 57.15 & 63.86 & 38.22 & 68.50 \\
\hline HFo & 4.50 & 6.96 & 3.85 & 7.31 & 3.47 & 3.48 & 3.50 \\
\hline HAc & 612.11 & 134.68 & 240.43 & 206.44 & 81.42 & 69.71 & 93.84 \\
\hline $\mathrm{HPr}$ & 550.64 & 89.55 & 297.79 & 173.42 & 74.61 & 51.18 & 82.14 \\
\hline $\mathrm{HIBu}$ & 6.29 & 88.17 & 48.30 & 81.68 & 85.61 & 86.74 & 73.76 \\
\hline $\mathrm{HBu}$ & 386.49 & 20.29 & 70.77 & 62.85 & 56.41 & 72.59 & 52.85 \\
\hline $\mathrm{HIVa}$ & 60.42 & 59.13 & 57.05 & 61.17 & 43.74 & 44.14 & 44.92 \\
\hline $\mathrm{MeOH}$ & 84.44 & 117.14 & 79.50 & 113.48 & 115.34 & 122.39 & 116.97 \\
\hline $\mathrm{EtOH}$ & 878.15 & 737.90 & 321.42 & 331.19 & 115.66 & 108.54 & 129.96 \\
\hline Suc & 5145 & 5675 & 8297 & 9570 & 9777 & 10879 & 11418 \\
\hline Bio & 590 & 1510 & 720 & 742 & 930 & 524 & 585 \\
\hline$C O D_{t, T}$ & 9913 & 9.188 & 10724 & 11647 & 11632 & 12191 & 12877 \\
\hline$C O D_{\exp }$ & 16775 & 24025 & 18025 & 23025 & 21050 & 20550 & 21550 \\
\hline$C O D_{\text {exp }}-C O D_{t, T}$ & 6862 & 14837 & 7301 & 11378 & 9418 & 8359 & 8673 \\
\hline $\begin{array}{c}\text { Agreement } \\
(A g, \%)\end{array}$ & 59 & 38 & 59 & 51 & 55 & 59 & 60 \\
\hline
\end{tabular}

\section{CONCLUDING REMARKS}

The greatest peaks of total SCOAs concentration were observed at intermediate levels adopted for initial $\mathrm{pH}$ and COD, i.e. 6.0 and $25 \mathrm{~g} \mathrm{COD} \mathrm{L}^{-1}$. Maximum of total SCOAs concentration for initial $\mathrm{pH}$ and COD of 7.5 and $30 \mathrm{~g}$ $\mathrm{COD} \mathrm{L}^{-1}$ (highest levels of both parameters) were also considerable, although lower than those verified under initial pH 6.0 and $25 \mathrm{~g} \mathrm{COD} \mathrm{L}^{-1}$ and occurring at incubation times further ahead. On the other hand, SCOAs generation seems to have been inhibited in experiments under initial $\mathrm{pH} 4.5$, regardless of COD level (20 or $30 \mathrm{~g} \mathrm{COD} \mathrm{L}^{-1}$ ), since maximum of metabolites contents in these cases were notably lower compared to those at other conditions.

Based on results of batch tests $\mathrm{B} 1-\mathrm{B} 7$, it was deduced that $\mathrm{pH}$ values nearer to neutrality, particularly at the two highest levels (6.0 and 7.5), were 
determining of occurrence of peaks of SCOAs concentrations. In this sense, even at the highest COD level $\left(30 \mathrm{~g} \mathrm{COD} \mathrm{L}^{-1}\right)$, which would tend to stimulate a greater production of metabolites due to higher content of carbon source available in fermentative medium, maximum of SCOAs concentrations verified under initial $\mathrm{pH} 4.5$ were lower than those observed under initial $\mathrm{pH} 6.0$ and 7.5 combined with the lowest levels of COD, i.e. 20 and $25 \mathrm{~g} \mathrm{COD} \mathrm{L}^{-1}$. Therefore, even at the lowest COD, higher initial $\mathrm{pH}$ values were decisive for obtaining greater maximum of total SCOAs concentration.

In most of incubation times, lactate contents were prevailing, suggesting that fermentative process followed an essentially lactic route. Consequently, concentration profiles of total SCOAs showed very similar behaviours to lactate concentration profiles. Aiming to explain this observation, the hypothesis of existence of a large number of microorganisms promoting lactic fermentation in cattle manure sludge was raised. However, it was not possible to accept or reject it definitely based only on obtained results. Moreover, considering that the prepared synthetic vinasse already contained pre-defined amounts of butyrate, acetate and propionate, production of these metabolites was taken as significant only at specific incubation times since their concentrations commonly fluctuated around the initial concentrations during the process, often being reduced to levels below those of the original substrate.

\section{ACKNOWLEDGMENTS}

Authors are grateful to CNPq (Brazilian National Council for Scientific and Technological Development - Finance Code 142340/2016-2) for scholarship and financial support for research and to FAPESP (The São Paulo Research Foundation), Program for Research on Bioenergy (BIOEN) - Regular Program Grants, grant number 2012/09785-8.

\section{REFERENCES}

1. AMORIM, N. C. S; ALVES, I.; MARTINS, J. S.; AMORIM, E. L. C. (2014). Biohydrogen production from cassava wastewater in an anaerobic fluidized bed reactor. Brazilian Journal of Chemical Engineering, 31(3), 603-612. dx.doi.org/10.1590/0104-6632.20140313s00002458.

2. APHA. (2012). Standard methods for the examination for water and wastewater. 22th ed. Washington, DC: American Public Health 
Association/American Water Works Association/Water Environmental Federation.

3. BAGHCHEHSARAEE, B.; NAKHLA, G.; KARAMANEV, D.; MARGARITIS, A.; REID, G. (2008). The effect of heat pretreatment temperature on fermentative hydrogen production using mixed cultures. International Journal of Hydrogen Energy, 33, 4064-4073.

4. BEGOT, C.; DESNIER, I.; DAUDIN, J. D.; LABADIE, J. C.; LEBERT, A. (1996). Recommendations for calculating growth parameters by optical density measurements. Journal of Microbiological Methods, 25(3), 225-232. doi:10.1016/0167-7012(95)00090-9.

5. BRITO, F. L.; ROLIM, M. M.; PEDROSA, E. M. R. (2009). Effect of vinasse application on chemical features of three soils from sugarcane zone of Pernambuco (in Portuguese). Agrária, 4(4), 456-462, doi:10.5039/agraria.v4i4a14.

6. CHEONG, D-Y.; HANSEN, C. L. (2006). Bacterial stress enrichment enhances anaerobic hydrogen production in cattle manure sludge. Applied Microbiology and Biotechnology, v. 72, p. 635-643.

7. COLLET, C.; SCHWITZGUEBEL, J.-P.; PERINGER, P. (2003). Improvement of acetate production from lactose by growing Clostridium thermolacticum in mixed batch culture. Journal of Applied Microbiology, 95(4), 824-831. doi:10.1046/j.1365-2672.2003.02060.x.

8. DAVILA-VAZQUEZ, G.; LEÓN-RODRÍGUEZ, A.; ALATRISTEMONDRAGÓN, F.; RAZO-FLORES, E. (2011). The buffer composition impacts the hydrogen production and the microbial community composition in non-axenic cultures. Biomass and Bioenergy, 35(7), 3174-3181. doi:10.1016/j.biombioe.2011.04.046.

9. DIAS, M. O. S.; MACIEL FILHO, R.; MANTELATTO, P. E.; CAVALETT, O.; ROSSELL, C. E. V.; BONOMI, A.; LEAL, M. R. L. V. (2015). Sugarcane processing for ethanol and sugar in Brazil. Environmental Development, 15, 35-51. doi:10.1016/j.envdev.2015.03.004.

10. DJUKIĆ-VUKOVIĆ, A. P.; MOJOVIĆ, L. V.; JOKIĆ, B. M.; NIKOLIĆ, S. B.; PEJIN, J. D. (2013). Lactic acid production on liquid distillery stillage by Lactobacillus rhamnosus immobilized onto zeolite. Bioresource Technology, 135, 454-458. doi:10.1016/j.biortech.2012.10.066

11.DJUKIĆ-VUKOVIĆ, A. P.; MOJOVIĆ, L. V.; SEMENČENKO, V. V.; RADOSAVLJEVIĆ, M. M.; PEJIN, J. D.; KOCIĆ-TANACKOV, S. D. (2015). Effective valorisation of distillery stillage by integrated production of lactic acid and high quality feed. Food Research International, 73, 75-80. doi:10.1016/j.foodres.2014.07.048.

12. DJUKIĆ-VUKOVIĆ, A.; MLADENOVIĆ, D.; RADOSAVLJEVIĆ, M.; KOCIĆTANACKOV, S.; PEJIN, J.; MOJOVIĆ, L. (2016). Wastes from bioethanol and beer productions as substrates for $L(+)$ lactic acid production - A comparative study. Waste Management, 48, 478-482. doi:10.1016/j.wasman.2015.11.031.

13. DUBOIS, S. M.; GILLES, K. A.; HAMILTON, J. K.; REBERS, P. A.; SMITH, F. (1956). Colorimetric Methods for determination of sugar and related substance. Analytical Chemistry, v.228, p.13-21. 
14.FANG, H.; LI, C.; ZHANG, T. (2006). Acidophilic biohydrogen production from rice slurry. International Journal of Hydrogen Energy, 31(6), 683-692. doi:10.1016/j.ijhydene.2005.07.005.

15. FLAMHOLZ, A.; NOOR, E.; BAR-EVEN, A.; MILO, R. (2011). eQuilibrator the biochemical thermodynamics calculator. Nucleic Acids Research, 40(D1), D770-D775. doi:10.1093/nar/gkr874.

16. FUESS, L. T., SANTOS, G. M., DELFORNO, T. P.; MORAES, B. S.; SILVA, A. J. (2020). Biochemical butyrate production via dark fermentation as an energetically efficient alternative management approach for vinasse in sugarcane biorefineries. Renewable Energy. doi:10.1016/j.renene.2020.05.063

17. FUESS, L. T.; GARCIA, M. L. (2014). Implications of stillage land disposal: A critical review on the impacts of fertigation. Journal of Environmental Management, 145, 210-229. doi:10.1016/j.jenvman.2014.07.003.

18. FUESS, L. T.; ZAIAT, M. (2018). Economics of anaerobic digestion for processing sugarcane vinasse: Applying sensitivity analysis to increase process profitability in diversified biogas applications. Process Safety and Environmental Protection, 115, 27-37. doi:10.1016/j.psep.2017.08.007.

19. GODOI, L. A. G.; FORESTI, E.; DAMIANOVIC, M. H. R. Z. (2017). Downflow fixed-structured bed reactor: An innovative reactor configuration applied to acid mine drainage treatment and metal recovery. Journal of Environmental Management, 197, 597-604. doi:10.1016/j.jenvman.2017.04.027

20. GUNKEL, G.; KOSMOL, J.; SOBRAL, M.; ROHN, H.; MONTENEGRO, S.; AURELIANO, J. (2006). Sugar Cane Industry as a Source of Water Pollution - Case Study on the Situation in Ipojuca River, Pernambuco, Brazil. Water, Air, and Soil Pollution, 180(1-4), 261-269. doi:10.1007/s11270-006-9268-x.

21. HAUS, S.; JABBARI, S.; MILLAT, T.; JANSSEN, H.; FISCHER, R.-J.; BAHL, H.; WOLKENHAUER, O. (2011). A systems biology approach to investigate the effect of $\mathrm{pH}$-induced gene regulation on solvent production by Clostridium acetobutylicum in continuous culture. BMC Systems Biology, 5(1), 10. doi:10.1186/1752-0509-5-10.

22. HOARAU, J.; CARO, Y.; GRONDIN, I.; PETIT, T. (2018). Sugarcane vinasse processing: Toward a status shift from waste to valuable resource. A review. Journal of Water Process Engineering, 24, 11-25. doi:10.1016/j.jwpe.2018.05.003.

23.JIANG, Z.-P.; LI, Y.-R.; WEI, G.-P.; LIAO, Q.; SU, T.-M.; MENG, Y.-C., ZHANG, H-Y.; LU, C.-Y. (2012). Effect of Long-Term Vinasse Application on Physico-chemical Properties of Sugarcane Field Soils. Sugar Technology, 14(4), 412-417. doi:10.1007/s12355-012-0174-9.

24. LAPPA, K.; KANDYLIS, P.; BASTAS, N.; KLAOUDATOS, S.; ATHANASOPOULOS, N.; BEKATOROU, A.; KANELLAKI, M.; KOUTINAS, A. A. (2015b). New generation biofuel: continuous acidogenesis of sucroseraffinose mixture simulating vinasse is promoted by $\mathrm{Y}$-alumina pellets. Biotechnology for Biofuels, 8(1). doi:10.1186/s13068-015-0255-6 
25. LAPPA, K.; KANDYLIS, P.; BEKATOROU, A.; BASTAS, N.; KLAOUDATOS, S.; ATHANASOPOULOS, N.; KANELLAKI, M.; KOUTINAS, A. A. (2015a). Continuous acidogenesis of sucrose, raffinose and vinasse using mineral kissiris as promoter. Bioresource Technology, 188, 43-48. doi:10.1016/j.biortech.2015.01.131

26. LI, T.; YAN, Y.; HE, J. (2014). Reducing cofactors contribute to the increase of butanol production by a wild-type Clostridium sp. strain $\mathrm{BOH}$. Bioresource Technology, 220-228. doi:10.1016/j.biortech.2013.12.089.

27. LIN, C.; HUNG, W. (2008). Enhancement of fermentative hydrogen/ethanol production from cellulose using mixed anaerobic cultures. International Journal of Hydrogen Energy, 33(14), 3660-3667. doi:10.1016/j.ijhydene.2008.04.036

28. LIU, J.; WANG, Q.; WANG, S.; SUN, X.; MA, H.; TUSHIRO, Y. (2012). Effects of pretreatment on the microbial community and I-lactic acid production in vinasse fermentation. Journal of Biotechnology, 164(2), 260265. doi:10.1016/j.jbiotec.2012.08.014.

29. MAAMRI, S.; AMRANI, M. (2014). Biogas production from waste activated sludge using cattle dung inoculums: Effect of total solid contents and kinetics study. Energy Procedia, v. 50, p. 352-359.

30. MARTINS, J. S.; AMORIM, E. L.C. (2016). Hydrogen production in anaerobic reactor from coconut processing wastewater (in Portuguese). Ciência \& Engenharia (Science \& Engineering Journal), 25(1), 17-26.

31. MONOT, F.; ENGASSER, J.M.; PETITDEMANGE, H. (1983). Regulation of acetone butanol production in batch and continuous cultures of Clostridium acetobutylicum. Biotechnology and Bioengineering Symposium, 13: 207216.

32. MONOT, F.; ENGASSER, J.-M.; PETITDEMANGE, H. (1984). Influence of $\mathrm{pH}$ and undissociated butyric acid on the production of acetone and butanol in batch cultures of Clostridium acetobutylicum. Applied Microbiology and Biotechnology, 19(6), 422-426. doi:10.1007/bf00454381.

33. MORAES, B. S.; SANTOS, G. M.; DELFORNO, T. P.; FUESS, L. T.; SILVA, A. J. (2019). Enriched microbial consortia for dark fermentation of sugarcane vinasse towards value-added short-chain organic acids and alcohol production. Journal of Bioscience and Bioengineering. 127(5), 594601. doi:10.1016/j.jbiosc.2018.10.008.

34. MORAES, B. S.; ZAIAT, M.; BONOMI, (2015). A. Anaerobic digestion of vinasse from sugarcane ethanol production in Brazil: Challenges and perspectives. Renewable and Sustainable Energy Reviews, 44, 888-903. doi:10.1016/j.rser.2015.01.023.

35. MOSEY, F. E. (1982). New Developments in the Anaerobic Treatment of Industrial Wastes. Water Pollution and Control, 4(81), 540-552.

36. OECD. (2015). Development of the World Ethanol Market. Available at http://www.oecd-ilibrary.org/content/graph/agr outlook-2015-graph105-en (November 19 2019).

37. PEIXOTO, G.; PANTOJA FILHO, J. L. R.; AGNELLI, J. A. B.; BARBOZA, M.; ZAIAT, M. (2012). Hydrogen and Methane Production, Energy Recovery, and Organic Matter Removal from Effluents in a Two-Stage 
Fermentative Process. Applied Biochemistry and Biotechnology, 168(3), 651-671. doi:10.1007/s12010-012-9807-4.

38. PENTEADO, E. D.; LAZARO, C. Z.; SAKAMOTO, I. K.; ZAIAT, M. (2013). Influence of seed sludge and pretreatment method on hydrogen production in packed-bed anaerobic reactors, International Journal of Hydrogen Energy, 38(14), 6137-6145. doi:10.1016/j.ijhydene.2013.01.067.

39. PREVINA, S.; SARAVANAN, A. D. (2013). Ecofriendly Utilization of Treated Distillery Effluent (TDE) and Inorganic Fertilizers Management on Microbial Population and Enzymatic Activities. International Journal of Scientific and Research Publications, 3(7), 1-6.

40.RFA. (2019). 2019 Industry Ethanol Outlook. Available at: https://ethanolrfa.org/wp-content/uploads/2019/02/RFA20190utlook.pdf (November 27 2019).

41. SILVA, F. C.; SERAFIM, L. S.; NADAIS, H.; ARROJA, L.; CAPELA, I. (2013). Acidogenic Fermentation Towards Valorisation of Organic Waste Streams into Volatile Fatty Acids. Chemical and Biochemical Engineering Quarterly, 27(4), 467-476.

42. SILVERIO, M. S.; CALEGARI, R. P.; LEITE, G. M. F. L.; MARTINS, B. C.; SILVA, E. A.; NETO, J. P.; CUSATIS, M. W.; GOMIG, A.; BAPTISTA, A. S. (2019). Biogas production from second generation ethanol vinasse (in Portuguese). In: Agronomia: Elo da Cadeira Produtiva 6 (Org.: SILVA, D. A. S.), 174-184. Ponta Grossa: Atena Editora.

43. SYDNEY, E. B.; LARROCHE, C.; NOVAK, A. C.; NOUAILLE, R.; SARMA, S. J.; BRAR, S. K.; LETTI, L. A. J.; SOCCOL, V. T. SOCCOL, C. R. (2014). Economic process to produce biohydrogen and volatile fatty acids by a mixed culture using vinasse from sugarcane ethanol industry as nutrient source. Bioresource Technology, 159, 380-386. doi:10.1016/j.biortech.2014.02.042.

44. TANISHO, S.; ISHIWATA, Y. (1994). Continuous hydrogen production from molasses by the bacterium Enterobacter aerogenes. International Journal of Hydrogen Energy, 19(10), 807-812. doi:10.1016/0360-3199(94)90197-x.

45. UYEDA, C. A.; MIRANDA, J. H.; DUARTE, S. N.; MEDEIROS, P. R. F.; DIAS, C. T. S. (2013). Influence of vinasse application in hydraulic conductivity of three soils. Engenharia Agrícola, 33(4), 689-698. doi:10.1590/s0100-69162013000400008.

46. VENTURA, J. R. S.; JAHNG, D. (2013). Improvement of Butanol Fermentation by Supplementation of Butyric Acid Produced from a Brown Alga. Biotechnology and Bioprocess Engineering, 18(6), 1142-1150. doi:10.1007/s12257-013-0150-6.

47.WANG, Q. (2002). Effects of anaerobic/aerobic incubation and storage temperature on preservation and deodorization of kitchen garbage. Bioresource Technology, 84(3), 213-220. doi:10.1016/s09608524(02)00062-7.

48. WANG, Q.; YAMABE, K.; NARITA, J.; MORISHITA, M.; OHSUMI, Y.; KUSANO, K.; SHIRAI, Y.; OGAWA, H. (2001). Suppression of growth of putrefactive and food poisoning bacteria by lactic acid fermentation of kitchen waste. Process Biochemistry, 37(4), 351-357. doi:10.1016/s00329592(01)00217-5.

49. WANG, Y-Y.; Al, P.; HU, C-X.; ZHANG, Y-L. (2011). Effects of various pretreatment methods of anaerobic mixed microflora on biohydrogen 
production and the fermentation pathway of glucose. International Journal of Hydrogen Energy, 36(1), 390-396. doi:10.1016/j.ijhydene.2010.09.092.

50.ZHANG, B.; ZHANG, L.-L.; ZHANG, S.-C.; SHI, H.-Z.; CAI, W.-M. (2005). The Influence of $\mathrm{pH}$ on Hydrolysis and Acidogenesis of Kitchen Wastes in Two-phase Anaerobic Digestion. Environmental Technology, 26(3), 329340. doi:10.1080/09593332608618563.

51. ZHANG, C.; YANG, H.; YANG, F.; MA, Y. (2009). Current Progress on Butyric Acid Production by Fermentation. Curr Microbiol, v.59, p. 656-663, 2009.

52. ZHOU, M.; ZHOU, J.; TAN, M.; DU, J.; YAN, B.; WONG, J. W. C.; ZHANG, Y. (2017). Enhanced carboxylic acids production by decreasing hydrogen partial pressure during acidogenic fermentation of glucose. Bioresource Technology, 245, 44-51. doi:10.1016/j.biortech.2017.08.152.

53. ZOETEMEYER, R. J.; VAN DEN HEUVEL, J. C.; COHEN, A. (1982). pH influence on acidogenic dissimilation of glucose in an anaerobic digestor. Water Research, 16(3), 303-311. doi:10.1016/0043-1354(82)90190-7.

54.ZONG, W.; YU, R.; ZHANG, P.; FAN, M.; ZHOU, Z. (2009). Efficient hydrogen gas production from cassava and food waste by a two-step process of dark fermentation and photo-fermentation. Biomass and Bioenergy, 33(10), 1458-1463. doi:10.1016/j.biombioe.2009.06.008. 